\title{
BTO 3.1.2.55 Milestone Report - Report of Literature Review for Maldistribution in Heat Exchangers
}

Approved for public release. Distribution is unlimited.
Viral K. Patel Ayyoub Momen Kashif Nawaz Ahmad Abu-Heiba Nathaniel O'Connor Jamal S. Yagoobi January 15, 2019 


\title{
DOCUMENT AVAILABILITY
}

Reports produced after January 1, 1996, are generally available free via US Department of Energy (DOE) SciTech Connect.

Website www.osti.gov

Reports produced before January 1, 1996, may be purchased by members of the public from the following source:

\author{
National Technical Information Service \\ 5285 Port Royal Road \\ Springfield, VA 22161 \\ Telephone 703-605-6000 (1-800-553-6847) \\ TDD 703-487-4639 \\ Fax 703-605-6900 \\ E-mail info@ntis.gov \\ Website http://classic.ntis.gov/
}

Reports are available to DOE employees, DOE contractors, Energy Technology Data Exchange representatives, and International Nuclear Information System representatives from the following source:

Office of Scientific and Technical Information

PO Box 62

Oak Ridge, TN 37831

Telephone 865-576-8401

Fax 865-576-5728

E-mail reports@osti.gov

Website http://www.osti.gov/contact.html

This report was prepared as an account of work sponsored by an agency of the United States Government. Neither the United States Government nor any agency thereof, nor any of their employees, makes any warranty, express or implied, or assumes any legal liability or responsibility for the accuracy, completeness, or usefulness of any information, apparatus, product, or process disclosed, or represents that its use would not infringe privately owned rights. Reference herein to any specific commercial product, process, or service by trade name, trademark, manufacturer, or otherwise, does not necessarily constitute or imply its endorsement, recommendation, or favoring by the United States Government or any agency thereof. The views and opinions of authors expressed herein do not necessarily state or reflect those of the United States Government or any agency thereof. 
Energy and Transportation Science Division

\title{
BTO 3.1.2.55 MILESTONE REPORT - REPORT OF LITERATURE REVIEW FOR MALDISTRIBUTION IN HEAT EXCHANGERS
}

\author{
Viral K. Patel ${ }^{1}$ \\ Ayyoub Momen ${ }^{1}$ \\ Kashif Nawaz ${ }^{1}$ \\ Ahmad Abu-Heiba ${ }^{1}$ \\ Nathaniel O'Connor ${ }^{2}$ \\ Jamal S. Yagoobi ${ }^{2}$
}

1: Building Equipment Research Group, ORNL

2: Multi Scale Heat Transfer Laboratory, Worcester Polytechnic Institute, Worcester, MA

Date Published: January 15, 2019

Prepared by

OAK RIDGE NATIONAL LABORATORY

Oak Ridge, TN 37831-6283

managed by

UT-BATTELLE, LLC

for the

US DEPARTMENT OF ENERGY

under contract DE-AC05-00OR22725 



\section{CONTENTS}

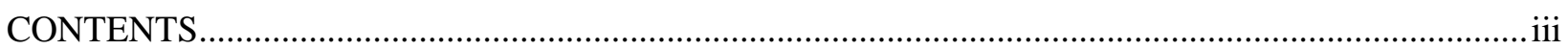

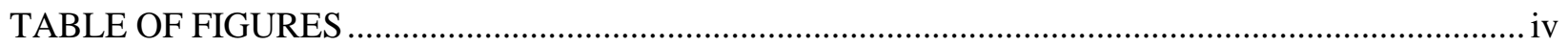

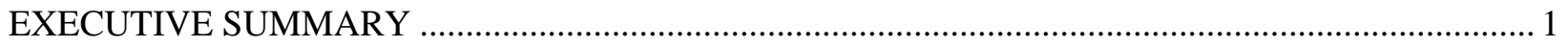

1. IMPACT OF MALDISTRIBUTION AND POTENTIAL ENERGY SAVINGS .......................... 2

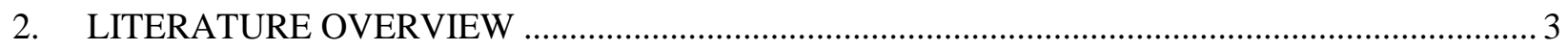

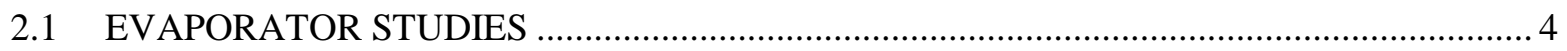

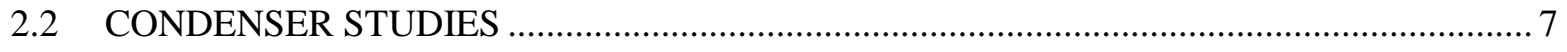

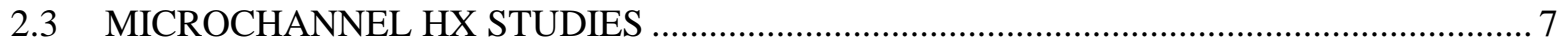

2.4 ALTERNATIVE FLOW CONTROL TECHNOLOGIES …............................................ 8

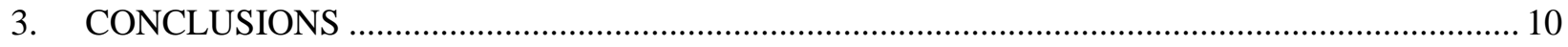

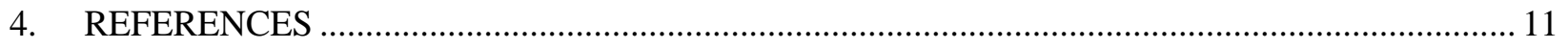

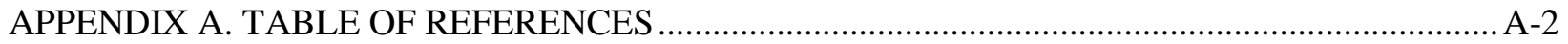




\section{TABLE OF FIGURES}

Figure 1. (a.) Primary approach of study (b.) Air-side vs. refrigerant-side studies ................................... 3

Figure 2. (a.) Number of studies based on HX type (i.e. evaporator, condenser or other) (b.)

Number of studies based on HX type.

Figure 3. Individual channel and coil capacity and COP vs. a. quality maldistribution, b. feeder tube bending, c. airflow maldistribution [11].

Figure 4. (a.) Reduction in cooling capacity compared with uniform air flow as a function of air flow maldistribution factor (b.) Reduction in system COP compared with uniform air flow as a function of air flow maldistribution factor [1] 


\section{EXECUTIVE SUMMARY}

In this quarter, a comprehensive review of the literature was performed to understand the effects of flow maldistribution and current efforts to improve performance through flow control. Nearly all systems have some degree of maldistribution on either the air-side, refrigerant-side, or both. Air-side maldistribution was found to have a greater impact on heat exchanger performance compared to refrigerant-side, but both sides of the system are important to consider when developing solutions. Up to a maximum of $65 \%$ capacity loss was reported in large commercial systems due to air-side maldistribution. Microchannel heat exchangers are becoming more widespread due to their efficiency and size but are even more prone to maldistribution than conventional fin-tube heat exchangers. Current solutions tend to focus on optimizing header design and refrigerant circuitry to improve performance. Several active control methods, such as hybrid control, have been explored to control refrigerant flow in real time, but there is a need for an adaptive yet cost effective system which can optimize performance in changing conditions. 


\section{IMPACT OF MALDISTRIBUTION AND POTENTIAL ENERGY SAVINGS}

Maldistribution in heat exchangers, both air-side and refrigerant-side, has been found to have a significant effect on heat exchanger performance and ultimately, system performance. Heat exchangers are typically designed assuming a uniform distribution of refrigerant in all branches or circuits or with passive features to make the distribution uniform (e.g. distributors with tubes of many different lengths). In practice, a perfect distribution of refrigerant in a real system is rare. Under certain external operating conditions, such as frosting, fouling, damage or blockage, it can even be advantageous to have an imbalance of refrigerant between branches to improve performance. For example, active flow control can be used to mitigate most performance loss due to an imposed air-side maldistribution [1]. Thus, maldistribution is an important area of study when seeking to improve the performance of heat exchangers.

Extensive studies have been performed to quantify the performance drop of heat exchangers due to maldistribution, many of which will be explored in detail in this literature review. Some of these studies also explore methods for mitigating the maldistribution in heat exchangers showing substantial performance recovery under controlled conditions.

Current solutions to address refrigerant maldistribution have been somewhat limited. This includes various electronically-actuated expansion valves (EEVs), smart refrigerant distributers, redesigned headers and tubes, or refrigerant circuitry interweaving and optimization. Complex header redesigns are likely cost prohibitive and not necessarily optimal under all operating conditions. Use of individual valves for each refrigerant circuit is also likely cost-prohibitive. Addressing air-side maldistribution is also challenging, especially regarding frosting and fouling. Improper installation, damage, or blockage can also lead to significant air-side maldistribution. Because of the uncontrollable nature of air-side maldistribution, most of the effort in the literature have been focused on refrigerant-side distribution.

There also has been recent development and interest in microchannel heat exchangers. Microchannels have several advantages, such as higher efficiency and compactness compared to conventional round tubes. This also allows for a smaller refrigerant charge for a similar capacity system. This is especially relevant with the push towards newer environmentally friendly but flammable A2L refrigerants. Microchannels are perhaps even more relevant in the study of maldistribution, as they are more susceptible to maldistribution due to the sudden and significant changes in area from header to channels. Therefore, studying maldistribution in microchannels could result in significant performance improvements and would help to further bring microchannel heat exchangers into mainstream use.

While most of the literature has been focused on understanding the causes and effects of maldistribution, few studies have explored new technologies to control maldistribution. A working solution with the potential to be retrofitted onto existing heat exchangers would have substantial energy savings potential. For example, a smart solution for mitigation of refrigerant maldistribution that is successfully implemented into current residential HVAC systems which results in a $10 \%$ improvement in system coefficient of performance (COP) can result in primary energy savings potential of up to $225 \mathrm{TBtu}$ for the 2030 energy market. 


\section{LITERATURE OVERVIEW}

In order to properly address the issue of maldistribution in heat exchangers, a thorough review of the literature is necessary to gain an understanding of the problem and available solutions. Previous studies on maldistribution have explored a wide variety of heat exchangers with varying system capacities, refrigerants, and technologies. This literature review will first give a broad overview of over 40 studies in the area of refrigerant maldistribution. Studies of greater relevance to the project will be examined in more detail. Studies are also grouped based on heat exchanger type in order to gain insight into which system should be directly addressed in this project. Finally, the sum contents of this literature review will aid in the determination of system parameters for the project, which will be chosen based on what is likely to have the greatest impact on industry.

The literature encompasses experimental, numerical, and analytical studies of many different systems of varying capacity and operating parameters. The parameters of interest include equipment type, maldistribution side, refrigerant, heat exchanger dimensions, capacity, nominal pressure range, nominal flow rate range, and the effect of maldistribution on capacity. While not all studies may list all these parameters, they were used to group and compare studies such that the most relevant system could be identified for the project.

The literature contains a nearly even distribution of both experimental and numerical studies. As shown in Figure 1, of the studies examined, $32 \%$ contained experimental work only, $36 \%$ contained numerical or analytical work only, and $32 \%$ contained both experimental and numerical work. Note that even though the numerical-only studies did not involve performing experiments, results were generally verified with experimental data from previous publications. Comparatively more studies focus on refrigerant-side maldistribution compared to air-side maldistribution: $52 \%$ of studies examined the refrigerant-side, $25 \%$ studies examined the air-side, and $23 \%$ studies examined both sides, which is arguably more important when trying to address issues with real commercially-available systems. The most commonly studied refrigerants were R-410a and R-134a, followed by water and other less common fluids. System capacities ranged from as small as $200 \mathrm{~W}$ up to as large as $26.4 \mathrm{~kW}$. Pressure and flow rate ranges are dependent on the refrigerant and system capacity and no significant trend was observed. The effect of maldistribution was typically reported as a percent capacity decrease for the HX. The literature indicates that air-side maldistribution can have a much greater impact on capacity compared to refrigerant-side maldistribution; up to a $65 \%$ decrease in capacity was reported in the most extreme cases [2]. This result is expected for air cooled systems, as the limiting thermal resistance is always air-side convection and thus any maldistribution will have major impact. A detailed table which includes information from all examined studies is given in APPENDIX A.

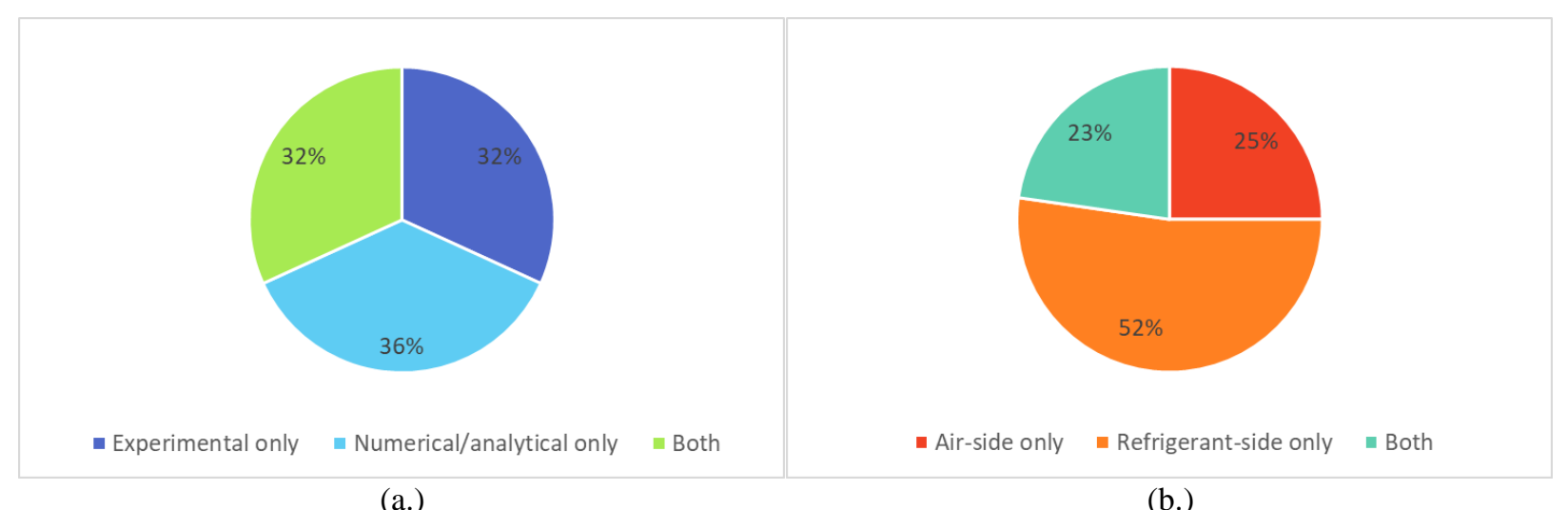

(a.)

(b.)

Figure 1. (a.) Primary approach of study (b.) Air-side vs. refrigerant-side studies 


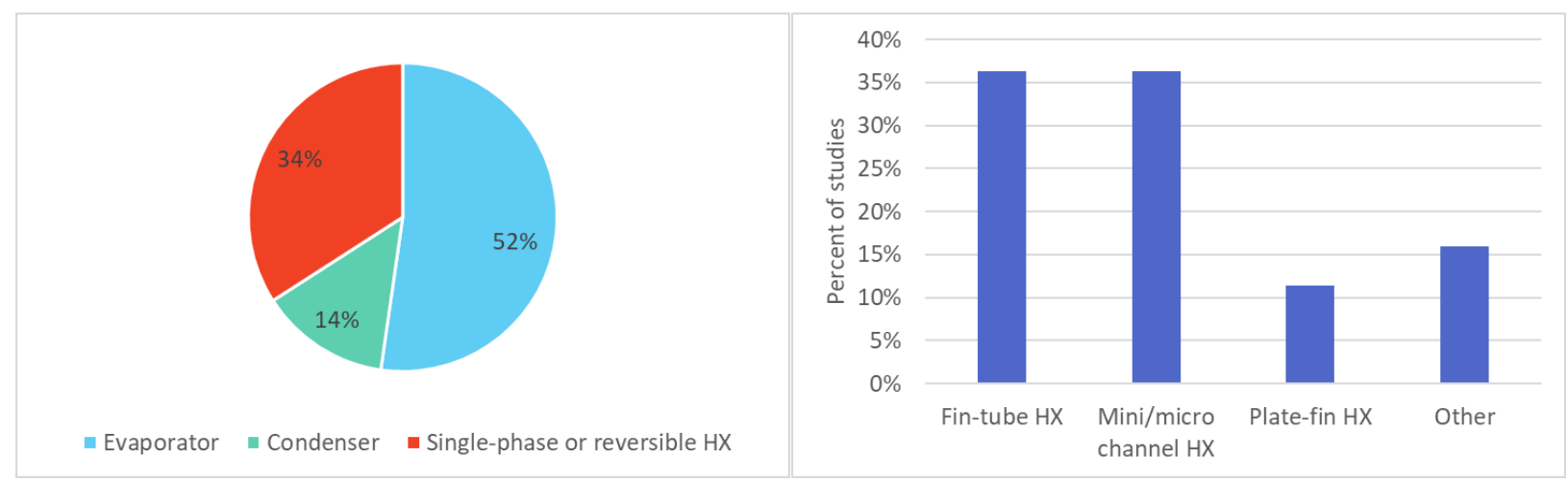

(a.)

(b.)

Figure 2. (a.) Number of studies based on HX type (i.e. evaporator, condenser or other) (b.) Number of studies based on HX type

Significantly more studies have been conducted on evaporators as compared to condensers, as illustrated in Figure 2a. This is likely due to the ease of controlling liquid-phase distribution entering the evaporator as opposed to the vapor-phase entering the condenser. In terms of the common HX types that are being studied, Figure $2 \mathrm{~b}$ shows that more recent work is focused on maldistribution in minichannel and microchannel heat exchangers, which seems to be reflective of industry trends towards higher heat transfer for a given mass flow rate. While many studies have been conducted to quantify the effects of maldistribution, relatively few solutions have been explored to actively mitigate maldistribution. Several studies have focused on the effects of header and distributer parameters and sought to optimize the design of headers to minimize refrigerant-side maldistribution [3, 4]. The studies focused on header design have tended to ignore cases of air-side maldistribution, which can result in situations where even refrigerant distribution is not optimal for performance. Very few active control systems have been studied in the literature. One such active system is hybrid control pioneered at Purdue University [1,5]. Hybrid control utilizes multiple electronic balancing valves to achieve even exit superheat throughout all circuits of a heat exchanger. Another active system is flow control through electrohydrodynamic (EHD) conduction pumping, which utilizes a coulomb force on a dielectric liquid to produce a net flow [6]. These active control systems are especially attractive due to their ability to redistribute flow in real time to maintain optimal performance of the system.

There are very few active systems being explored in the literature, and thus a cost-effective solution could have a substantial impact. Upstream evaporator control appears to be the most relevant area to address based on existing studies. A smaller capacity system would be better for the testing and development of an active control system. The increasing prevalence of microchannel heat exchangers is also a significant factor to consider when selecting systems to study. Based on these overall trends, preliminary parameters can be chosen for a system to be modelled and experimentally studied.

\subsection{EVAPORATOR STUDIES}

The literature contains studies on evaporators in many different systems, ranging from HXs in large rooftop units (RTUs) to smaller microchannel heat exchangers used for refrigeration and heat pump systems. These studies not only seek to quantify the effect of maldistribution, but also offer some novel methods of measuring maldistribution (e.g. [7]). These evaporator studies tend to dominate the literature, likely due to ease of control and visualization of the liquid phase entering the evaporator. New methods for control of refrigerant distribution, such as "hybrid control" pioneered by Kim et al. [1] are able to achieve substantial performance recovery due to maldistribution. While many studies focused on conventional finned-tube evaporators, many newer studies are exploring microchannel heat exchangers for their efficiency [7-10]. 
Groll et al. in Ref. [2] studied maldistribution in three different systems: a large room cooling system (LRCS), a domestic heat pump, and a rooftop unit (RTU) with economizer. These large commercial systems were tested under a variety of operating conditions to see the effect of maldistribution on capacity. Each system was first tested with an EEV which did not allow for individual refrigerant control through HX tubes. This was compared to individual circuit refrigerant flow control using a hybrid control system. Significant improvement in COP and capacity was achieved if air-side maldistribution was applied. They concluded that anywhere from $4 \%$ to $26 \%$ of capacity could be lost depending on environmental factors. Kærn et al. [11] simulated a vapor compression cycle for a residential air conditioning unit to explore the effects of different types of maldistribution. It was found that air-side maldistribution has a much greater effect on capacity than quality maldistribution and feeder tube bending, with a maximum capacity loss of up to $43.2 \%$. The effect of varying maldistributions on capacity are shown in Figure 3.
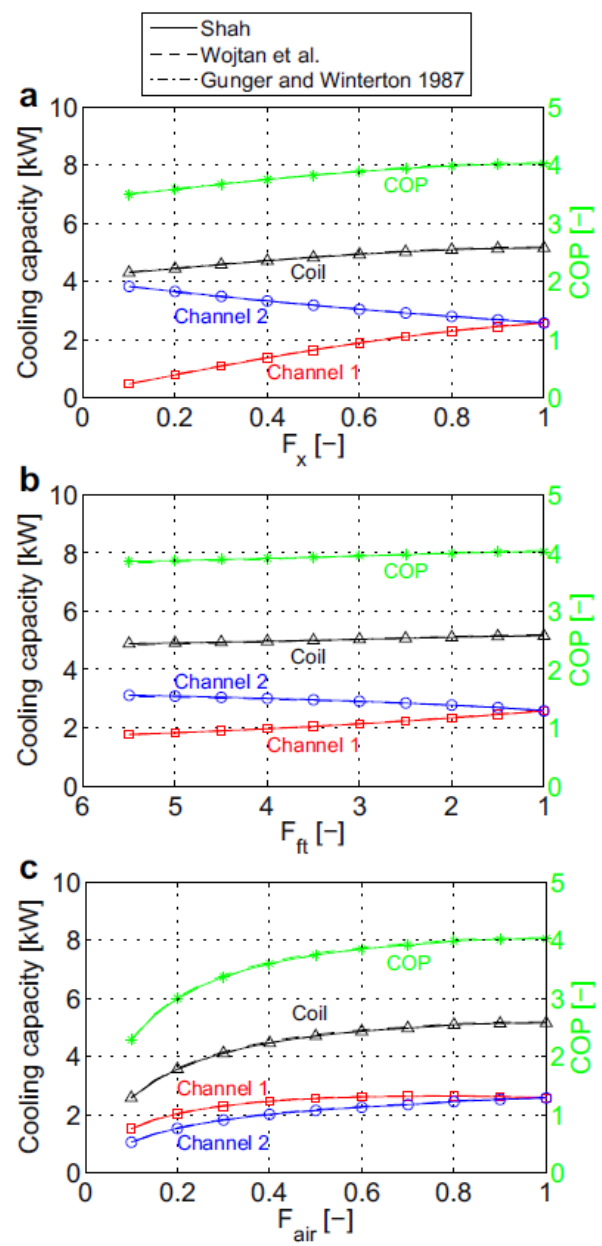

Figure 3. Individual channel and coil capacity and COP vs. a. quality maldistribution, b. feeder tube bending, c. airflow maldistribution [11]

The $\mathrm{x}$-axis in each graph represents the measured distribution parameter, where $\mathrm{F}_{\mathrm{x}}$ is the ratio of tube quality to inlet quality, $\mathrm{F}_{\mathrm{ft}}$ is the feeder tube bending parameter used to multiply frictional pressure drop, and $\mathrm{F}_{\text {air }}$ was the ratio of airflow velocity over one tube to the mean frontal velocity across both tubes. Aganda et al. [12] studied the effect air-side maldistribution on a room air conditioner, resulting in a similar maximum capacity loss of $38 \%$. Bach et al. $[5,13]$ numerically studied both air and refrigerant maldistribution on a walk-in cooler evaporator and found a maximum capacity loss of up to $22 \%$. This 
shows there is significant room for improvement and capacity recovery in current commercially available systems.

Many studies have been focused on header and distributer design in order to more evenly distribute refrigerant. Byun and Kim $[9,14]$ studied the effects of mass flux and inlet/outlet locations for HXs with vertical headers and horizontal minichannel evaporator tubes. They found that thermal degradation by flow maldistribution is larger for a top row-crossing header than for a bottom row-crossing header. Zhang et al. [4] investigated the effect of distributer configuration in plate-fin heat exchangers. They found that improved distributers were very effective in improving flow distribution. By incorporating their improved header, they were able to reduce the flow non-uniformity by up to 57.4\%. Payne and Domanski [15] explored the use of smart distributers to mitigate performance loss due to maldistribution. They found that significant performance recovery could be achieved by controlling the exit superheats between circuits. Even for significant coil blockage resulting in significantly increase pressure drop, performance was able to be restored within $2 \%$ of the original evenly distributed system. They also found that additional capacity degradation occurs when imposing an excessive superheat due to heat transfer between tubes, likely due to conduction through the fins of the heat exchanger. Habib et al. [3] investigated the effect of various header parameters on the effect of maldistribution. Flow maldistribution was characterized by the standard deviation of flow rate between tubes. Their results showed that Reynolds number was only significant for low flow rate systems. Locating the header inlet at the center resulted in $25-30 \%$ reduction in the standard deviation of the flow rate. Increasing the number of inlet nozzles had an insignificant effect but increasing the nozzle diameters resulted in an increase in the standard deviation of flow rate and an increase in pressure drop across the tubes.

While water is not typically used as a refrigerant in commercial systems, some studies like the above are using it to study maldistribution. A unique study by Razlan et al. [16] sought to compare the two-phase flow of refrigerant to an air-water mixture. They found that under the right conditions, an air-water mixture can be used to accurately represent two-phase flow, and thus is a safe and effective method for exploring flow maldistribution. According to Razlan et al. [16], the greatest similarity in flow pattern occurred when the Baker map (i.e. two-phase flow pattern map) parameters of both flows were equal. Another unique study by Brix et al. [8] modelled flow distribution in parallel minichannels using $\mathrm{CO}_{2}$ as the refrigerant. They used this model to study the effects of uneven inlet quality and air-side maldistribution. They showed that non-uniform airflow leads to significant capacity reduction of the evaporator, while inlet quality seems to have a less significant effect. The results were very similar to those obtained using R134a, further extending the idea of using alternative fluids as the refrigerant when studying maldistribution.

In addition to alternative refrigerants, new methods for measurement of flow maldistribution are being explored. Li and Hrnjak [7] are pioneering an infrared thermography approach to measure liquid distribution in parallel microchannel heat exchangers. Flow through each tube is quantified by relating the liquid mass flow rate and the air-side capacity calculated from measurement of the tube wall temperature. This method was validated against experimental data to prove its accuracy and has the potential to be used for measurements on a wide variety of heat exchangers. Linde presented, in a thesis, a unique experimental setup for flow visualization through a transparent multiport header [10]. The setup was able to visualize the flow of refrigerant going into varying hardware through the transparent header and enabled the study of varying inlet header geometry, tube number, tube pitch, refrigerant, heat load, inlet location and mass flow rate on maldistribution. Flow visualization is typically difficult due to the need for suitable transparent materials but can offer greater insight into the phenomenon of maldistribution. 


\subsection{CONDENSER STUDIES}

There are fewer studies focused specifically on the condenser sections of commercial heat exchangers. This is likely because upstream control of vapor is more difficult, and downstream control of liquid is less effective. These studies tend to report a lesser capacity degradation compared to evaporators, even with substantial air-side maldistribution. The literature was also dominated by numerical studies of condensers, which typically focused only on the refrigerant-side maldistribution.

Chin [17] performed a numerical study of a wavy fin and tube condenser and showed that single-phase and two-phase flow tend to follow similar trends in performance degradation due to maldistribution, with a maximum capacity degradation of up to $9 \%$. Mao et al. [18] performed a numerical study on a multilouvered fin and flat tube condenser prototype with varying air-side maldistribution and found a maximum capacity decrease of $6 \%$ and a $34 \%$ increase in pressure drop across the condenser. Chng et al. [19] numerically modelled refrigerant-side maldistribution in a microchannel condenser using a deterioration factor relating to the standard deviation of the maldistribution profile. Their model agrees with experimental evidence of reduction in performance as the standard deviation of maldistribution increased.

Active upstream control of a condenser has not often been explored due to the challenges associated with the vapor phase. Once such control method explored by Feng and Yagoobi [6] utilized electrohydrodynamic (EHD) condition pumping of dielectric fluids. A perforated electrode was used to impose a coulomb force on the dielectric liquid and generate pressure. With this method, the two-phase distribution between two parallel branches was able to be controlled, however, the EHD conduction pump is only able to influence the liquid-phase flow and its effect is also limited by the flowrate across the pump.

\subsection{MICROCHANNEL HX STUDIES}

More recent studies have begun to explore minichannel and microchannel heat exchangers due to their efficiency and compactness. Their increased efficiency is due to a smaller surface area to volume ratio resulting in greater heat transfer for a given flow rate. However, minichannel and microchannel systems are potentially more susceptible to refrigerant side maldistribution due to the sudden and extreme decrease in area from the header to the channels. Thus, there is potential for significant performance improvements of these systems if maldistribution could be mitigated or controlled. The following paragraphs provide an overview of recent studies involving flow distribution in microchannels.

Brix et al. [8] as previously mentioned performed a numerical study of a minichannel evaporator using $\mathrm{CO}_{2}$ as the working fluid and explored the effects of air-side maldistribution and uneven inlet quality on performance. Their results showed that air-flow nonuniformity has a much greater impact on performance. $\mathrm{CO}_{2}$ had the advantage of being more stable than conventional refrigerants since there is less of a density difference between the liquid and vapor phases, but for a horizontal orientation the results were very similar for those of R134a. Huang et al. [20] developed a co-simulation approach for modeling flow maldistribution in the header of a microchannel heat exchanger. The effect of gravity and air-side maldistribution was analyzed and compared to experimental data for an automotive condenser. The co-simulation approach resulted in a heat load within $1 \%$ of experimental data. Zou, Li and Hrnjak [21] studied the effect of polyalkylene glycol (PAG) oil added to R134a on distribution in a microchannel heat exchanger header. They found that with a small addition of oil $(0.5 \%)$ the distribution worsened, but with increasing amounts of oil (2.5\% and $4.7 \%)$ the distribution improved. Zou, Tuo, and Hrnjak [22] also studied flow through a transparent header in a microchannel heat exchanger. A microchannel evaporator model using experimental results numerically evaluated heat exchanger performance. A single pass heat exchanger resulted in a capacity degradation of up to $40 \%$ compared to a uniform refrigerant 
distribution. The maldistribution is even more significant in a two-pass heat exchanger, and thus its capacity is even lower than the single pass case. Zuo and Hrnjak [23] explored an outdoor reversible microchannel heat exchanger and examined the effects of inlet conditions, header geometries, and fluid properties on two-phase flow maldistribution in the header. A transparent header was used for visualization to gain insight into which flow regimes contribute to maldistribution. They concluded that the size of the churn flow region most affects the flow distribution and the best distribution occurs at high mass flux when the churn flow region immerses all microchannel inlets. The previously mentioned properties affect the size of the churn flow region and thus influence flow distribution.

\subsection{ALTERNATIVE FLOW CONTROL TECHNOLOGIES}

While the literature universally agrees that flow maldistribution has serious effects on the performance of heat exchangers and is found to occur in most commercial heat exchangers, there are a limited number of solutions being actively explored. Passive methods for control of flow maldistribution typically involve optimizing the headers of heat exchangers, but this lacks the robustness to account for external and environmental factors which may lead to maldistribution. In a real system, environmental factors can significantly affect the air-side of a heat exchanger, through frosting, fouling, or blockage. In these cases, it can be advantageous to increase the refrigerant flow rate in specific circuits in order to maximize performance. This is only possible with active control methods, of which there are few being examined in the literature.

The passive methods of improving refrigerant flow maldistribution typically use flowrate as a control parameter. Achieving equal flowrate through all tubes is ideal when the system is exposed to a uniform airflow. Several studies in the literature focus on header redesign and optimization. Byun and Kim [14] studied the effects of inlet location, outlet location, and mass flux on flow distribution and capacity for parallel heat exchangers with vertical headers. They found that flow distribution was improved using a top inlet configuration and top or bottom outlet configuration due to gravitational effects forcing more liquid flow to the bottom tubes of the heat exchanger. As previously mentioned, Byun and Kim [9] also explored the differences between top and bottom row-crossing headers in a similar study. They showed that thermal degradation by flow maldistribution was larger for the top row-crossing header configuration. Habib et al. [3] studied the influence of inlet nozzle parameters, such as location, diameter, number of nozzles, and inlet flow Reynold's number on flow maldistribution. Jiao et al. [24] experimented with implementation of a second header to mitigate flow maldistribution. They found that flow became more uniform when the inlet and outlet diameter ratios for both headers were equal and showed that performance of a plate-fin heat exchanger could be improved with optimal header design. Mohan et al. [25] performed a numerical parametric study of varying channel diameter on flow maldistribution and found that a more uniform distribution could be achieved by varying the diameters in individual channels. This is similar to a numerical study by Said et al. [26] in which vena-contracta of tube inlets were normalized to evenly distribute flow. In the previously mentioned study by Zou et al. [21], a passive technique of adding varying amounts of PAG oil to refrigerant was found to improve distribution. Yashar et al. [27] numerically optimized the circuitry of a 7.5-ton commercial R-410a rooftop unit and were able to achieve marginal performance improvements. While many of these studies of passive methods of improving performance through flow distribution were able to achieve significant recovery, they lack the capacity to adapt to changing conditions to maintain optimal performance.

Active flow control systems seek to address the need for changing operating conditions, but relatively few active control methods are being explored. The two most prominently being explored in the literature are hybrid control and electrohydrodynamic (EHD) conduction pumping. Hybrid control is a method pioneered by Kim et al. [1] involving small balancing valves on individual circuits in a heat exchanger. They were able to achieve substantial performance recovery by controlling and normalizing the exit superheat of each circuit in the evaporator. Through numerical simulations, they were able to impose non- 
uniform airflow over the tubes and still recover to near $100 \%$ of original capacity. Additionally, they compared the effect of upstream control versus downstream control and found that upstream control was more effective in all cases of air-side maldistribution. Figure 4 below shows the condensed results of Kim et al. [1], where the airflow maldistribution factor is defined as the difference in airflow between circuits 2 and 1 divided by the airflow in circuit 2 .

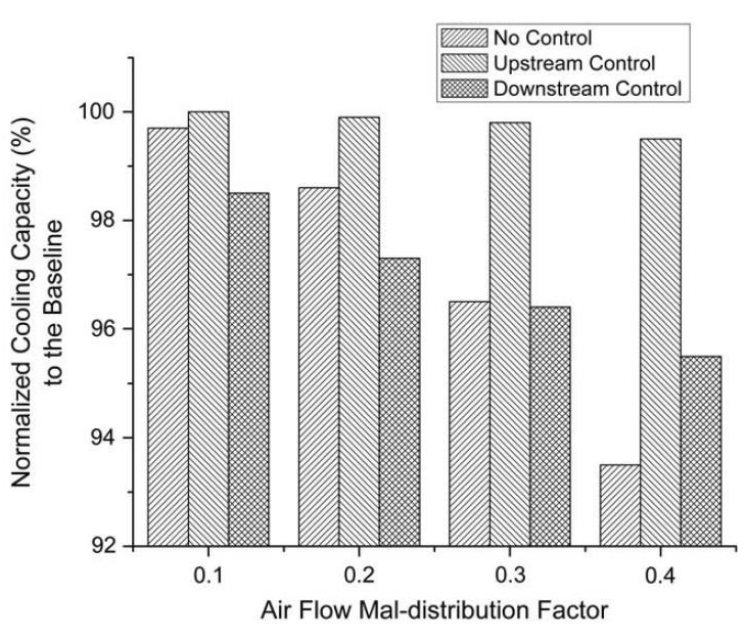

(a.)

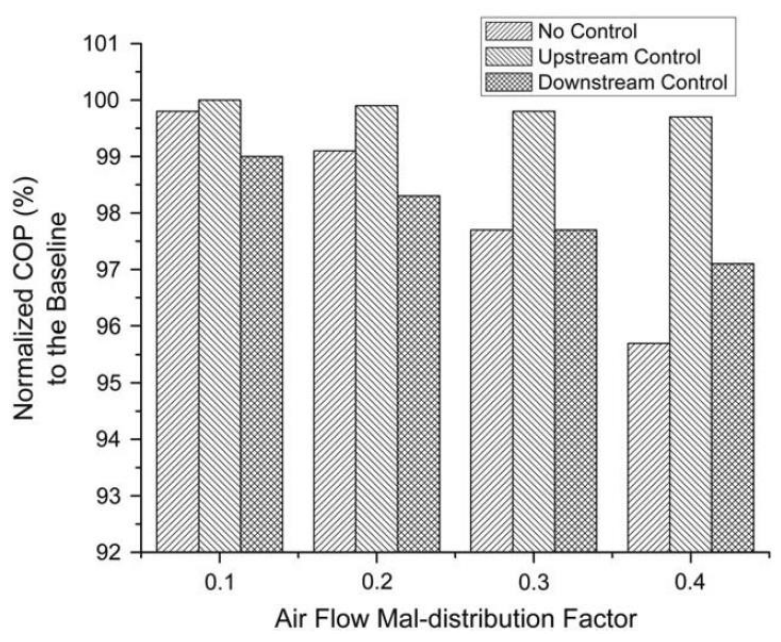

(b.)

Figure 4. (a.) Reduction in cooling capacity compared with uniform air flow as a function of air flow maldistribution factor (b.) Reduction in system COP compared with uniform air flow as a function of air flow maldistribution factor [1]

Hybrid control has been explored in several other studies with positive results. Bach et al. $[5,13]$ found that active hybrid control of refrigerant flow showed better performance recovery compared to passive interleaved circuitry. Groll et al. [2] examined 3 different systems and compared the effect of a single electronic expansion valve compared to individual circuit hybrid control. They found that hybrid control could achieve significant performance recovery up to $65 \%$ in a 5-ton system. Exit superheat was the parameter being normalized to achieve performance recovery in these studies and is likely to be relevant for any other future active control methods.

Another technology for active flow control currently being explored is electrohydrodynamic (EHD) conduction pumping. EHD conduction pumping is a phenomenon that uses an applied electric field to impart a coulomb force on a dielectric liquid through its naturally occurring electrolytic impurities [6]. More recent studies such as Yang et al. [28] have begun to bring EHD conduction pumping to smaller scale system and have the potential to be implemented into microchannel heat exchangers. EHD conduction pumping has been shown to be an effective flow control technology with the capability to generate over $1 \mathrm{kPa}$ of pressure with minimal power consumption. EHD conduction pumping has some limitations which prevent widespread adoption. The working fluid in the system must be a strong dielectric fluid, so this is particularly appealing to electronics cooling. Additionally, the pressure generation is highly dependent on the flowrate with lower pressure generated at a higher flowrate. The mechanism is also only able to influence the liquid phase and thus is only able to be implemented under specific conditions. While these active control methods are currently being explored, each has various limitations or barriers to widespread implementation. Therefore, there is still a need for development of low cost and effective active flow control systems to mitigate the performance losses caused by maldistribution. 


\section{CONCLUSIONS}

Maldistribution is present to some degree in all systems whether air-side or refrigerant-side. Based on the literature examined, evaporators have the greatest potential for capacity improvement through mitigation of maldistribution. An increasing number of recent studies on microchannel heat exchangers aligns with industry trend due to their increased efficiency, compactness, and lower charger volume with adoption of A2L refrigerants. Maldistribution also tends to be more prevalent in microchannel heat exchangers due to the substantial reduction in area from header to channel. Thus, the study of maldistribution in microchannel heat exchangers appears to have the greatest potential impact.

Many heat exchangers are designed assuming uniform refrigerant and air distribution but in a real system there is always some amount of maldistribution present. When comparing air-side and refrigerant-side maldistribution, it is obvious that air-side maldistribution will have a greater impact on capacity. This is because the limiting thermal resistance is always air-side convection, and any reduction in airflow over part of the heat exchanger will have substantial impact on the capacity of those affected areas. While the air-side is primarily the limiting factor, it is often impractical to precisely control the distribution of air, and therefore most control methods focus on refrigerant distribution.

Passive solutions to refrigerant maldistribution, such as optimized header design, can result in an even flowrate between circuits in a heat exchanger. However, these passive solutions cannot account for changing environmental conditions surrounding the system. This could include improper installation, damage, or blockage due to frost, fouling, or debris. In these cases of imposed air-side maldistribution, optimal performance would inherently require an uneven balance of refrigerant between tubes. In order to be able to compensate for these situations, and active flow control system is required. Based on this literature review, very few active control methods are currently being explored. Thus, there exists a need for a low-cost and adaptive system which could be implemented into current and future heat exchangers to optimize performance in all situations. 


\section{REFERENCES}

[1] Kim, J.-H., Braun, J. E., and Groll, E. A., 2009, "A hybrid method for refrigerant flow balancing in multi-circuit evaporators: Upstream versus downstream flow control," International Journal of Refrigeration, 32(6), pp. 1271-1282.

[2] Groll, E. A., Braun, J. E., and Bach, C. K., 2011, "CEC-500-2013-089 - Optimizing Refrigerant Distribution in Evaporators," Report, Prepared for the California Energy Commission by Purdue University.

[3] Habib, M., Said, S., Khalifa, A., Nemitallah, M., and Ayinde, T., 2014, "Experimental Investigation of the Flow Maldistribution Inside an Air-Cooled Heat Exchanger," Arabian Journal for Science \& Engineering, 39(11), pp. 8187-8198.

[4] Zhang, Z., Mehendale, S., Tian, J., and Li, Y., 2015, "Experimental investigation of distributor configuration on flow maldistribution in plate-fin heat exchangers," Applied Thermal Engineering, 85, pp. 111-123.

[5] Bach, C. K., Groll, E. A., Braun, J. E., and Horton, W. T., 2013, "Application of a hybrid control of expansion valves to a domestic heat pump and a walk-in cooler refrigeration system," HVAC\&R Research, 19(7), pp. 800-813.

[6] Feng, Y., and Seyed-Yagoobi, J., 2006, "Control of adiabatic two-phase dielectric fluid flow distribution with EHD conduction pumping," Journal of electrostatics, 64(7-9), pp. 621-627.

[7] Li, H., and Hrnjak, P., 2015, "Quantification of liquid refrigerant distribution in parallel flow microchannel heat exchanger using infrared thermography," Applied Thermal Engineering, 78, pp. 410418.

[8] Brix, W., Kærn, M. R., and Elmegaard, B., 2010, "Modelling distribution of evaporating CO2 in parallel minichannels," International Journal of Refrigeration, 33(6), pp. 1086-1094.

[9] Byun, H.-W., and Kim, N.-H., 2016, "Two-phase refrigerant distribution in a two row/four pass parallel flow minichannel heat exchanger," Experimental Thermal and Fluid Science, 77, pp. 10-27. [10] Linde, J. E., 2005, "Construction of a test facility to measure and visualize refrigerant maldistribution in multiport evaporator headers," Master of Science Thesis, University of Maryland, College Park, MD. [11] Kærn, M. R., Brix, W., Elmegaard, B., and Larsen, L. F. S., 2011, "Performance of residential airconditioning systems with flow maldistribution in fin-and-tube evaporators," International Journal of Refrigeration, 34(3), pp. 696-706.

[12] Aganda, A., Coney, J., and Sheppard, C., 2000, "Airflow maldistribution and the performance of a packaged air conditioning unit evaporator," Applied Thermal Engineering, 20(6), pp. 515-528. 
[13] Bach, C. K., Groll, E. A., Braun, J. E., and Horton, W. T., 2014, "Mitigation of air flow maldistribution in evaporators," Applied Thermal Engineering, 73(1), pp. 879-887.

[14] Byun, H. W., and Kim, N. H., 2011, "Refrigerant distribution in a parallel flow heat exchanger having vertical headers and heated horizontal tubes," Experimental Thermal and Fluid Science, 35(6), pp. 920-932.

[15] Payne, W. V., and Domanski, P. A., 2002, "ARTI-2 ICR/605-200-50-1 - Potential benefits of smart refrigerant distributors," Report, Prepared for the Air-conditioning and Refrigeration Technology Institute by the National Institute of Standards and Technology.

[16] Razlan, Z. M., Bakar, S. A., Desa, H., Wan, W. K., Zunaidi, I., Ibrahim, I., Kamarrudin, N. S., Ridzuan, M. J. M., Takiguchi, K., Tsuchiya, T., Kitade, Y., Hirota, M., Maruyama, N., and Nishimura, A., 2018, "Experimental study on gas-liquid flow distributions in upward multi-pass channelsComparison of R-134a flow and air-water flow," Experimental Thermal and Fluid Science, 91, pp. 134143.

[17] Chin, W., 2017, "On the Phenomenon of Two-phase Flow Maldistribution in a Heat Exchanger Undergoing Condensation," Journal of Engineering Science Technology, 12(8), pp. 2028-2045.

[18] Mao, J., Chen, H., Jia, H., Wang, Y., and Hu, H., 2013, "Effect of air-side flow maldistribution on thermal-hydraulic performance of the multi-louvered fin and tube heat exchanger," International Journal of Thermal Sciences, 73, pp. 46-57.

[19] Chng, M., Chin, W., and Tang, S., 2017, "Analysis on the refrigerant (R32) flow maldistribution of microchannel heat exchanger under superheat and sub-cool," International Journal of Automotive and Mechanical Engineering, 14, pp. 4140-4157.

[20] Huang, L., Lee, M. S., Saleh, K., Aute, V., and Radermacher, R., 2014, "A computational fluid dynamics and effectiveness-NTU based co-simulation approach for flow mal-distribution analysis in microchannel heat exchanger headers," Applied Thermal Engineering, 65(1-2), pp. 447-457.

[21] Zou, Y., Li, H., and Hrnjak, P. S., 2014, "R134a and PAG Oil Maldistribution and Its Impact On Microchannel Heat Exchanger Performance," Proc. 2014 ASHRAE Winter Conference, New York, NY, ASHRAE Transactions.

[22] Zou, Y., Tuo, H., and Hrnjak, P. S., 2014, "R-410A Maldistribution Impact on the Performance of Microchannel Evaporator," ASHRAE Transactions, 120(1).

[23] Zou, Y., and Hrnjak, P., 2014, "ACRC TR-303 - Refrigerant flow distribution in vertical headers of reversible microchannel heat exchangers," Report, Air Conditioning and Refrigeration Center at the University of Illinois at Urbana-Champaign.

[24] Jiao, A., Zhang, R., and Jeong, S., 2003, "Experimental investigation of header configuration on flow maldistribution in plate-fin heat exchanger," Applied Thermal Engineering, 23(10), pp. 1235-1246. 
[25] Mohan, K. P., Santosh, S. M., Ramakanth, M., Thansekhar, M., and Venkatesan, M., 2014, "Analysis of Flow Mal-Distribution in a Cross-Flow Heat Exchanger," Proc. Applied Mechanics and Materials, Trans Tech Publ, pp. 1428-1432.

[26] Said, S., Ben-Mansour, R., Habib, M., and Siddiqui, M., 2015, "Reducing the flow mal-distribution in a heat exchanger," Computers \& Fluids, 107, pp. 1-10.

[27] Yashar, D. A., Lee, S., and Domanski, P. A., 2015, "Rooftop air-conditioning unit performance improvement using refrigerant circuitry optimization," Applied Thermal Engineering, 83, pp. 81-87. [28] Yang, L., Talmor, M., Shaw, B. C., Minchev, K. S., Jiang, C., and Seyed-Yagoobi, J., 2017, "Flow distribution control in meso scale via electrohydrodynamic conduction pumping," IEEE Transactions on Industry Applications, 53(2), pp. 1431-1438.

[29] Chin, W. M., and Raghavan, V. R., 2011, "On the adverse influence of higher statistical moments of flow maldistribution on the performance of a heat exchanger," International Journal of Thermal Sciences, 50(4), pp. 581-591.

[30] Choi, J. M., Payne, W. V., and Domanski, P. A., 2003, "Effects of non-uniform refrigerant and air flow distributions on finned-tube evaporator performance," Proc. International Congress Refrigeration, Washington, DC.

[31] Elgowainy, A., 2003, "Effect of airflow maldistribution on pressure drop and thermal performance of heat exchangers in residential heat pump systems," ASHRAE Transactions, 109, p. 9.

[32] Inamdar, H. V., Groll, E. A., Weibel, J. A., and Garimella, S. V., 2016, "Prediction of air-side particulate fouling of HVAC\&R heat exchangers," Applied Thermal Engineering, 104, pp. 720-733.

[33] Kærn, M. R., Elmegaard, B., and Larsen, L. F. S., 2009, "Effect of refrigerant mal-distribution in finand-tube evaporators on system performance," Proc. 50th International Conference of Scandinavian Simulation Society, Fredericia, Denmark, Technical University of Denmark (DTU).

[34] Lee, M. S., Li, Z., Ling, J., and Aute, V., 2018, "A CFD assisted segmented control volume based heat exchanger model for simulation of air-to-refrigerant heat exchanger with air flow mal-distribution," Applied Thermal Engineering, 131, pp. 230-243.

[35] Mohammadi, K., and Malayeri, M., 2013, "Parametric study of gross flow maldistribution in a single-pass shell and tube heat exchanger in turbulent regime," International Journal of Heat \& Fluid Flow, 44, pp. 14-27.

[36] Ozawa, M., Akagawa, K., and Sakaguchi, T., 1989, "Flow instabilities in parallel-channel flow systems of gas-liquid two-phase mixtures," International Journal of Multiphase Flow, 15(4), pp. 639-657. [37] Rossetti, A., Minetto, S., and Marinetti, S., 2015, "A simplified thermal CFD approach to fins and tube heat exchanger: Application to maldistributed airflow on an open display cabinet," International Journal of Refrigeration, 57, pp. 208-215. 
[38] Shojaeefard, M. H., Nourbakhsh, S. D., and Zare, J., 2017, "An investigation of the effects of geometry design on refrigerant flow mal-distribution in parallel flow condenser using a hybrid method of finite element approach and CFD simulation," Applied Thermal Engineering, 112, pp. 431-449.

[39] Tuo, H., and Hrnjak, P., 2013, "Effect of the header pressure drop induced flow maldistribution on the microchannel evaporator performance," International Journal of Refrigeration, 36(8), pp. 2176-2186. [40] Vist, S., and Pettersen, J., 2004, "Two-phase flow distribution in compact heat exchanger manifolds," Experimental Thermal and Fluid Science, 28(2), pp. 209-215.

[41] Wen, J., Li, Y., Zhou, A., Zhang, K., and Wang, J., 2006, "PIV experimental investigation of entrance configuration on flow maldistribution in plate-fin heat exchanger," Cryogenics, 46(1), pp. 37-48. [42] Yaïci, W., Ghorab, M., and Entchev, E., 2016, "3D CFD study of the effect of inlet air flow maldistribution on plate-fin-tube heat exchanger design and thermal-hydraulic performance," International Journal of Heat and Mass Transfer, 101, pp. 527-541.

[43] Yang, H., Wen, J., Gu, X., Liu, Y., Wang, S., Cai, W., and Li, Y., 2017, "A mathematical model for flow maldistribution study in a parallel plate-fin heat exchanger," Applied Thermal Engineering, 121, pp. 462-472.

[44] Zou, Y., Tuo, H., and Hrnjak, P. S., 2014, "Modeling refrigerant maldistribution in microchannel heat exchangers with vertical headers based on experimentally developed distribution results," Applied Thermal Engineering, 64(1), pp. 172-181. 
APPENDIX A. TABLE OF REFERENCES 
APPENDIX A. TABLE OF REFERENCES

\begin{tabular}{|c|c|c|c|c|c|c|c|c|c|c|c|c|}
\hline $\begin{array}{c}\text { Reference } \\
\text { name \& year }\end{array}$ & 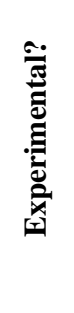 & 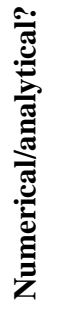 & Equipment type & 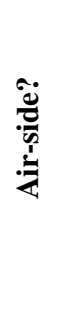 & 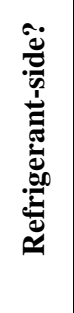 & Refrigerant & $\begin{array}{l}\text { HX type and general } \\
\text { dimensions }\end{array}$ & $\begin{array}{l}\text { Nominal } \\
\text { HX } \\
\text { capacity }\end{array}$ & $\begin{array}{l}\text { Nominal } \\
\text { refrigerant } \\
\text { pressure } \\
\text { range }\end{array}$ & $\begin{array}{l}\text { Nominal } \\
\text { refrigerant } \\
\text { flow rate } \\
\text { range }\end{array}$ & $\begin{array}{l}\text { Maldistribution } \\
\text { effect on HX } \\
\text { capacity }\end{array}$ & Notes \\
\hline $\begin{array}{l}\text { Aganda et } \\
\text { al., } 2000 \\
{[12]}\end{array}$ & $x$ & & $\begin{array}{l}\text { Room Air } \\
\text { Conditioner }\end{array}$ & $x$ & & $\mathrm{R}-22$ & $\begin{array}{l}\text { Evaporator, } 7 \text { circuits } \\
\text { with } 5 \text { rows of tubes, } \\
9.525 \mathrm{~mm} \text { ID copper } \\
\text { tubing with } \\
\text { aluminum plate fins }\end{array}$ & $\begin{array}{l}\text { Not } \\
\text { stated }\end{array}$ & $598 \mathrm{kPa}$ & $\begin{array}{c}0.0159 \\
\mathrm{~kg} / \mathrm{s}\end{array}$ & Up to $38 \%$ & $\begin{array}{l}\text { Air maldistribution led } \\
\text { to reduced refrigerant } \\
\text { flow and up to } 38 \% \\
\text { HX capacity loss }\end{array}$ \\
\hline $\begin{array}{l}\text { Bach et al., } \\
2013 \text { [5] }\end{array}$ & $\times$ & & $\begin{array}{l}\text { 3-ton walk-in cooler } \\
\text { refrigeration system } \\
\text { and 5-ton domestic } \\
\text { HP }\end{array}$ & & & $\begin{array}{l}\text { R-404a, R- } \\
410 a\end{array}$ & Fin-tube evaporator & $\begin{array}{c}10.6- \\
17.6 \mathrm{~kW}\end{array}$ & $\begin{array}{c}400- \\
2500 \mathrm{kPa}\end{array}$ & Not stated & Up to $30 \%$ & $\begin{array}{l}\text { Compared flow control } \\
\text { using TXV, EXV and } \\
\text { hybrid control by } \\
\text { matching evaporator } \\
\text { exit superheats }\end{array}$ \\
\hline $\begin{array}{l}\text { Bach et al., } \\
2014 \text { [13] }\end{array}$ & & $x$ & $\begin{array}{l}\text { 3-ton walk-in cooler } \\
\text { refrigeration system }\end{array}$ & $x$ & $x$ & R404a & $\begin{array}{l}\text { Fin-tube evaporator, } \\
8 \text { circuit (partial } \\
\text { simulation) }\end{array}$ & $\begin{array}{l}10.6 \mathrm{~kW} \\
\text { (partial) }\end{array}$ & $450 \mathrm{kPa}$ & Not stated & Up to $28 \%$ & $\begin{array}{l}\text { Active (hybrid control) } \\
\text { mitigation of } \\
\text { refrigerant and air } \\
\text { maldistribution showed } \\
\text { better performance } \\
\text { recovery compared to } \\
\text { passive (interleaved } \\
\text { circuitry) }\end{array}$ \\
\hline $\begin{array}{l}\text { Brix et al., } \\
2010[8]\end{array}$ & & $x$ & $\begin{array}{l}\text { General - two parallel } \\
\text { minichannels }\end{array}$ & $\times$ & $x$ & $\mathrm{CO}_{2}$ & $\begin{array}{l}\text { Minichannel } \\
\text { evaporator, } 2 \text { tubes, } \\
11 \text { ports, } 0.8 \times 1.2 \\
\mathrm{~mm}\end{array}$ & $300 \mathrm{~W}$ & $4200 \mathrm{kPa}$ & $2 \mathrm{~g} / \mathrm{s}$ & Up to $40 \%$ & $\begin{array}{l}\text { Air flow non- } \\
\text { uniformity induced } \\
\text { significant refrigerant } \\
\text { maldistribution and } \\
\text { capacity degradation, } \\
\text { more-so than uneven } \\
\text { inlet quality }\end{array}$ \\
\hline
\end{tabular}




\begin{tabular}{|c|c|c|c|c|c|c|c|c|c|c|c|c|}
\hline $\begin{array}{c}\text { Reference } \\
\text { name \& year }\end{array}$ & 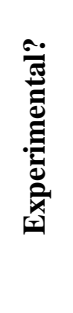 & 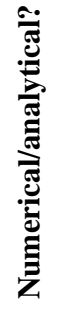 & Equipment type & 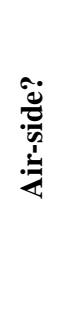 & 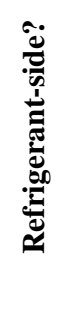 & Refrigerant & $\begin{array}{l}\text { HX type and general } \\
\text { dimensions }\end{array}$ & $\begin{array}{c}\text { Nominal } \\
\text { HX } \\
\text { capacity }\end{array}$ & $\begin{array}{l}\text { Nominal } \\
\text { refrigerant } \\
\text { pressure } \\
\text { range }\end{array}$ & $\begin{array}{l}\text { Nominal } \\
\text { refrigerant } \\
\text { flow rate } \\
\text { range }\end{array}$ & $\begin{array}{l}\text { Maldistribution } \\
\text { effect on HX } \\
\text { capacity }\end{array}$ & Notes \\
\hline $\begin{array}{l}\text { Byun and } \\
\text { Kim, } 2011 \\
{[14]}\end{array}$ & $x$ & & $\begin{array}{l}\text { General - parallel } \\
\text { flow HX for typical } \\
\text { residential AC }\end{array}$ & & $x$ & R-410a & $\begin{array}{l}\text { Minichannel } \\
\text { evaporator, vertical } \\
\text { headers, } 18 \text { horizontal } \\
\text { flat tubes, hydraulic } \\
\text { diameter: } 1.32 \mathrm{~mm} \text {, } \\
\text { length: } 780 \mathrm{~mm}\end{array}$ & $1 \mathrm{~kW}$ & $1100 \mathrm{kPa}$ & $\begin{array}{c}50-70 \\
\mathrm{~kg} / \mathrm{m}^{\wedge} 2 \mathrm{~s}\end{array}$ & Up to $13 \%$ & $\begin{array}{l}\text { Studied effects of } \\
\text { inlet/outlet location on } \\
\text { vertical headers and } \\
\text { mass flux on flow } \\
\text { distribution and } \\
\text { capacity }\end{array}$ \\
\hline $\begin{array}{l}\text { Byun and } \\
\text { Kim, } 2016 \\
{[9]}\end{array}$ & $x$ & & $\begin{array}{l}\text { General - two } \\
\text { row/four pass parallel } \\
\text { minichannel HX }\end{array}$ & & $x$ & R-410a & $\begin{array}{l}\text { Minichannel } \\
\text { evaporator, } 2 \text { row, } 4 \\
\text { pass, horizontal } \\
\text { headers, } 18 \text { vertical } \\
\text { flat tubes, hydraulic } \\
\text { diameter: } 1.19 \mathrm{~mm} \text {, } \\
\text { length: } 910 \mathrm{~mm}\end{array}$ & $1 \mathrm{~kW}$ & $1100 \mathrm{kPa}$ & $\begin{array}{l}70-130 \\
\mathrm{~kg} / \mathrm{m}^{\wedge} 2 \mathrm{~s}\end{array}$ & Up to $28 \%$ & $\begin{array}{l}\text { Similar setup as above } \\
\text { thermal degradation by } \\
\text { flow maldistribution is } \\
\text { larger for top row- } \\
\text { crossing header than } \\
\text { for bottom config. }\end{array}$ \\
\hline $\begin{array}{l}\text { Chin and } \\
\text { Raghavan, } \\
2011 \text { [29] }\end{array}$ & & $x$ & $\begin{array}{l}\text { General - simulated } \\
\text { crossflow HX }\end{array}$ & $x$ & & Water & $\begin{array}{l}\text { Fin-tube cross flow } \\
\text { HX, } 2 \text { pass with } 5 \\
\text { tubes }\end{array}$ & $\begin{array}{l}\text { Not } \\
\text { stated }\end{array}$ & Not stated & $4.2 \mathrm{~kg} / \mathrm{s}$ & Not stated & $\begin{array}{l}\text { The first two statistical } \\
\text { moments of the } \\
\text { velocity distribution } \\
\text { (i.e. mean and standarc } \\
\text { deviation) were found } \\
\text { to have the highest } \\
\text { effect on HX } \\
\text { performance } \\
\text { degradation }\end{array}$ \\
\hline $\begin{array}{l}\text { Chin, } 2017 \\
{[17]}\end{array}$ & & $x$ & $\begin{array}{l}\text { General - simulated } \\
\text { crossflow HX }\end{array}$ & & $\times$ & $\mathrm{R}-22$ & $\begin{array}{l}\text { Fin-tube cross flow } \\
\text { condenser, } 3 \text { rows, } 10 \\
\text { circuits, OD: } 9.52 \\
\text { mm, length: } 2000 \\
\text { mm }\end{array}$ & $\begin{array}{l}\text { Not } \\
\text { stated }\end{array}$ & $1950 \mathrm{kPa}$ & $\begin{array}{c}20-80 \\
\mathrm{~kg} / \mathrm{h}\end{array}$ & Up to $9 \%$ & $\begin{array}{l}\text { As above, thermal } \\
\text { degradation of the HX } \\
\text { is strongly dependent } \\
\text { on statistical moments } \\
\text { of the flow profile and } \\
\text { changing vapor quality } \\
\text { along the flow } \\
\text { direction }\end{array}$ \\
\hline
\end{tabular}




\begin{tabular}{|c|c|c|c|c|c|c|c|c|c|c|c|c|}
\hline $\begin{array}{c}\text { Reference } \\
\text { name \& year }\end{array}$ & 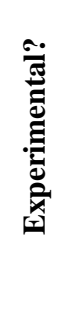 & 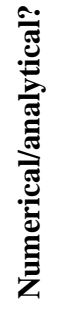 & Equipment type & 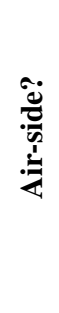 & 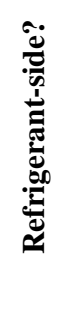 & Refrigerant & $\begin{array}{l}\text { HX type and general } \\
\text { dimensions }\end{array}$ & $\begin{array}{l}\text { Nominal } \\
\text { HX } \\
\text { capacity }\end{array}$ & $\begin{array}{l}\text { Nominal } \\
\text { refrigerant } \\
\text { pressure } \\
\text { range }\end{array}$ & $\begin{array}{l}\text { Nominal } \\
\text { refrigerant } \\
\text { flow rate } \\
\text { range }\end{array}$ & $\begin{array}{l}\text { Maldistribution } \\
\text { effect on HX } \\
\text { capacity }\end{array}$ & Notes \\
\hline $\begin{array}{l}\text { Chng et al., } \\
2017 \text { [19] }\end{array}$ & $x$ & $\times$ & $\begin{array}{l}\text { General - } \\
\text { microchannel HX }\end{array}$ & & $x$ & $\mathrm{R}-32$ & $\begin{array}{l}\text { Microchannel } \\
\text { condenser, } 10 \text { tubes, } \\
\text { hyd. diameter: } 0.83 \\
\text { mm, length: } 1700 \\
\mathrm{~mm}\end{array}$ & $\begin{array}{c}0.41- \\
3.2 \mathrm{~kW}\end{array}$ & Not stated & $\begin{array}{l}14.29- \\
43.05 \\
\mathrm{~kg} / \mathrm{hr}\end{array}$ & Up to $8 \%$ & $\begin{array}{l}\text { As above, thermal } \\
\text { degradation of the HX } \\
\text { is strongly dependent } \\
\text { on statistical moments } \\
\text { of the flow profile. } \\
\text { Superheat and } \\
\text { subcooling effects } \\
\text { were also studied. }\end{array}$ \\
\hline $\begin{array}{l}\text { Choi et al., } \\
2003 \text { [30] }\end{array}$ & $x$ & & $\begin{array}{l}\text { General - fin-tube } \\
\text { evaporator }\end{array}$ & $\times$ & $x$ & $\mathrm{R}-22$ & $\begin{array}{l}\text { Fin-tube evaporator, } \\
3 \text { rows, } 3 \text { parallel } \\
\text { circuits, } 54 \text { tubes, } \\
\text { OD: } 9.53 \mathrm{~mm}\end{array}$ & $7 \mathrm{~kW}$ & $1560 \mathrm{kPa}$ & Not stated & Up to $30 \%$ & $\begin{array}{l}\text { Individual exp. valves } \\
\text { used for superheat } \\
\text { control of each circuit. } \\
\text { Capacity degradation } \\
\text { was high even at } \\
\text { uniform superheat } \\
\text { when air flow was } \\
\text { maldistributed. }\end{array}$ \\
\hline $\begin{array}{l}\text { Elgowainy, } \\
2003 \text { [31] }\end{array}$ & & $x$ & $\begin{array}{l}\text { Residential heat } \\
\text { pump }\end{array}$ & $x$ & & Not stated & $\begin{array}{l}\text { Fin-tube } \\
\text { evaporator/condenser, } \\
1 \text { row, } 5 \text { tubes, OD: } \\
10 \mathrm{~mm}\end{array}$ & $\begin{array}{l}\text { Not } \\
\text { stated }\end{array}$ & Not stated & Not stated & Not stated & $\begin{array}{l}\text { Mass-averaged } \\
\text { pressure drop was } \\
\text { predicted to be } 9 \% \\
\text { greater for non- } \\
\text { uniform vs. uniform air } \\
\text { flow. Similarly, area- } \\
\text { averaged air-side heat } \\
\text { transfer coefficient was } \\
\text { predicted to be } 1.5 \% \\
\text { less for non-uniform } \\
\text { vs. uniform flow. }\end{array}$ \\
\hline $\begin{array}{l}\text { Feng and } \\
\text { Yagoobi, } \\
2005[6]\end{array}$ & $x$ & & $\begin{array}{l}\text { General - two-phase } \\
\text { flow control using } \\
\text { electrohydrodynamics }\end{array}$ & & $x$ & HCFC-123 & $\begin{array}{l}\text { Condenser, } 2 \\
\text { branches, ID: } 10.2 \\
\text { mm, length: } 1.5 \mathrm{~m}\end{array}$ & $\begin{array}{l}\text { Not } \\
\text { stated }\end{array}$ & $100 \mathrm{kPa}$ & $\begin{array}{l}50-100 \\
\mathrm{~kg} / \mathrm{m}^{\wedge} 2 \mathrm{~s}\end{array}$ & Not stated & $\begin{array}{l}\text { Used EHD conduction } \\
\text { pumping to control } \\
\text { two-phase flow } \\
\text { distribution between }\end{array}$ \\
\hline
\end{tabular}




\begin{tabular}{|c|c|c|c|c|c|c|c|c|c|c|c|c|}
\hline $\begin{array}{c}\text { Reference } \\
\text { name \& year }\end{array}$ & 泀 & 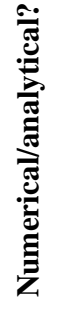 & Equipment type & 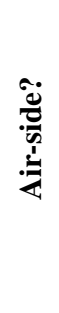 & 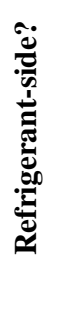 & Refrigerant & $\begin{array}{l}\text { HX type and general } \\
\text { dimensions }\end{array}$ & $\begin{array}{l}\text { Nominal } \\
\text { HX } \\
\text { capacity }\end{array}$ & $\begin{array}{c}\text { Nominal } \\
\text { refrigerant } \\
\text { pressure } \\
\text { range }\end{array}$ & $\begin{array}{l}\text { Nominal } \\
\text { refrigerant } \\
\text { flow rate } \\
\text { range }\end{array}$ & $\begin{array}{l}\text { Maldistribution } \\
\text { effect on HX } \\
\text { capacity }\end{array}$ & Notes \\
\hline & & & & & & & & & & & & $\begin{array}{l}\text { two HX branches with } \\
\text { varying inlet quality }\end{array}$ \\
\hline \multirow[t]{3}{*}{$\begin{array}{l}\text { Groll et al. } \\
\text { (CEC } \\
\text { report), } \\
2011[2]\end{array}$} & $x$ & & $\begin{array}{l}\text { Large room cooling } \\
\text { system }\end{array}$ & $x$ & $x$ & R-404a & $\begin{array}{l}\text { Fin-tube evaporator, } \\
8 \text { circuits }\end{array}$ & $10.6 \mathrm{~kW}$ & $\begin{array}{c}400- \\
2000 \mathrm{kPa}\end{array}$ & $80 \mathrm{~g} / \mathrm{s}$ & Up to $29 \%$ & $\begin{array}{l}\text { Each system was first } \\
\text { tested with an EEV } \\
\text { which did not allow for } \\
\text { individual refrigerant } \\
\text { control through HX } \\
\text { tubes. This was } \\
\text { compared to individual } \\
\text { circuit refrigerant flow } \\
\text { control using a hybrid } \\
\text { control system. } \\
\text { Significant } \\
\text { improvement in COP } \\
\text { and capacity was } \\
\text { achieved if air-side } \\
\text { maldistribution was } \\
\text { applied. }\end{array}$ \\
\hline & $x$ & & Domestic heat pump & $x$ & $x$ & R-410a & $\begin{array}{l}\text { Fin-tube } \\
\text { evaporator/condenser, } \\
9 \text { circuits }(4 \text { with } 10 \\
\text { tubes and } 5 \text { with } 8 \\
\text { tubes) }\end{array}$ & $17.6 \mathrm{~kW}$ & $\begin{array}{c}800- \\
2500 \mathrm{kPa}\end{array}$ & $28-80 \mathrm{~g} / \mathrm{s}$ & Up to $26 \%$ & \\
\hline & $x$ & & $\begin{array}{l}\text { Rooftop air- } \\
\text { conditioner }\end{array}$ & $x$ & $x$ & R-410a & $\begin{array}{l}\text { Fin-tube evaporator, } \\
6 \text { circuits, } 14 \text { tubes }\end{array}$ & $14.0 \mathrm{~kW}$ & $\begin{array}{c}800- \\
4000 \mathrm{kPa}\end{array}$ & $40-80 \mathrm{~g} / \mathrm{s}$ & Up to $65 \%$ & \\
\hline $\begin{array}{l}\text { Habib et al., } \\
2014 \text { [3] }\end{array}$ & $x$ & & $\begin{array}{l}\text { General - parallel } \\
\text { tubes to simulate } \\
\text { industrial air-cooled } \\
\text { HX }\end{array}$ & & $x$ & Water & $\begin{array}{l}\text { Single-phase HX, } 16 \\
\text { tubes }\end{array}$ & $\begin{array}{l}\text { Not } \\
\text { stated }\end{array}$ & Not stated & $\begin{array}{c}2.84-5.93 \\
\mathrm{~kg} / \mathrm{s}\end{array}$ & Not stated & $\begin{array}{l}\text { Study focused on } \\
\text { adjusting inlet to } \\
\text { header parameters to } \\
\text { see effect on } \\
\text { maldistribution }\end{array}$ \\
\hline
\end{tabular}




\begin{tabular}{|c|c|c|c|c|c|c|c|c|c|c|c|c|}
\hline $\begin{array}{c}\text { Reference } \\
\text { name \& year }\end{array}$ & 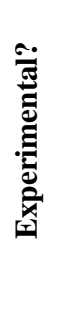 & 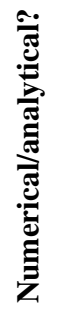 & Equipment type & 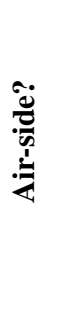 & 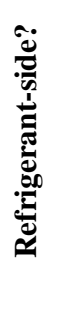 & Refrigerant & $\begin{array}{l}\text { HX type and general } \\
\text { dimensions }\end{array}$ & $\begin{array}{l}\text { Nominal } \\
\text { HX } \\
\text { capacity }\end{array}$ & $\begin{array}{l}\text { Nominal } \\
\text { refrigerant } \\
\text { pressure } \\
\text { range }\end{array}$ & $\begin{array}{l}\text { Nominal } \\
\text { refrigerant } \\
\text { flow rate } \\
\text { range }\end{array}$ & $\begin{array}{l}\text { Maldistribution } \\
\text { effect on HX } \\
\text { capacity }\end{array}$ & Notes \\
\hline $\begin{array}{l}\text { Huang et al., } \\
2014 \text { [20] }\end{array}$ & & $x$ & $\begin{array}{l}\text { General - } \\
\text { microchannel HX }\end{array}$ & $x$ & $x$ & $\begin{array}{l}\text { R-134a, } \\
\text { water }\end{array}$ & $\begin{array}{l}\text { Microchannel HX, } 10 \\
\text { tubes, } 2 \times 30 \mathrm{~mm}, 13 \\
\text { ports }(1 \times 1 \mathrm{~mm}), \\
\text { length: } 180 \mathrm{~mm}\end{array}$ & $\begin{array}{c}3.5-7.8 \\
\mathrm{~kW}\end{array}$ & $\begin{array}{c}101- \\
1470 \mathrm{kPa}\end{array}$ & $21 \mathrm{~g} / \mathrm{s}$ & Not stated & $\begin{array}{l}\text { Co-simulation } \\
\text { approach combined } \\
\text { detailed header CFD } \\
\text { with effectiveness- } \\
\text { based finite volume } \\
\text { tube-side heat transfer } \\
\text { and refrigerant flow } \\
\text { modeling tool. }\end{array}$ \\
\hline $\begin{array}{l}\text { Inamdar et } \\
\text { al., 2016 } \\
\text { [32] }\end{array}$ & & $\times$ & General - fin-tube HX & $x$ & & Water & $\begin{array}{l}\text { Fin-tube HX, model } \\
\text { based on dimensions } \\
\text { from multiple other } \\
\text { studies }\end{array}$ & $\begin{array}{l}\text { Not } \\
\text { stated }\end{array}$ & $101 \mathrm{kPa}$ & Not stated & Not stated & $\begin{array}{l}\text { Model of the } \\
\text { deposition of particles } \\
\text { on the air-side surfaces } \\
\text { of fin-tube HXs }\end{array}$ \\
\hline $\begin{array}{l}\text { Jiao et al., } \\
2003 \text { [24] }\end{array}$ & $x$ & & $\begin{array}{l}\text { General - plate-fin } \\
\text { HX }\end{array}$ & & $x$ & Water & $\begin{array}{l}\text { Plate-fin HX, } 1100 \\
\text { cold-flow and } 1000 \\
\text { hot-flow } \\
\text { micropassages, fin } \\
\text { dimensions: } 6.5 \text { x } 2 \times \\
0.3 \mathrm{~mm}^{\wedge} 3\end{array}$ & $\begin{array}{l}\text { Not } \\
\text { stated }\end{array}$ & $101 \mathrm{kPa}$ & $\begin{array}{c}\text { Mean } \\
\text { velocity: } \\
0.3-0.4 \\
\mathrm{~m} / \mathrm{s}\end{array}$ & Not stated & $\begin{array}{l}\text { Second header added } \\
\text { to plate-fin HX to aid } \\
\text { in flow distribution; } \\
\text { effects of inlet pipe, } \\
\text { first header and second } \\
\text { header diameters } \\
\text { studied on flow } \\
\text { distribution. }\end{array}$ \\
\hline $\begin{array}{l}\text { Kærn et al., } \\
2009 \text { [33] }\end{array}$ & & $\times$ & Room air-conditioner & $x$ & $x$ & R-410a & $\begin{array}{l}\text { Fin-tube evaporator, } \\
2 \text { tubes, ID: } 7.6 \mathrm{~mm} \text {, } \\
\text { OD: } 9.6 \mathrm{~mm} \text {, length: } \\
7 \mathrm{~m}\end{array}$ & $\begin{array}{l}\text { Not } \\
\text { stated }\end{array}$ & $\begin{array}{c}1000- \\
3000 \mathrm{kPa}\end{array}$ & $\begin{array}{l}100-600 \\
\mathrm{~kg} / \mathrm{m}^{\wedge} 2 \mathrm{~s}\end{array}$ & Up to $38 \%$ & $\begin{array}{l}\text { Study shows that air- } \\
\text { flow maldistribution } \\
\text { has a more significant } \\
\text { effect than a } \\
\text { malfunctioning } \\
\text { distributer; however } \\
\text { most loss can be } \\
\text { recovered by } \\
\text { controlling individual } \\
\text { tube superheats }\end{array}$ \\
\hline
\end{tabular}




\begin{tabular}{|c|c|c|c|c|c|c|c|c|c|c|c|c|}
\hline $\begin{array}{c}\text { Reference } \\
\text { name \& year }\end{array}$ & 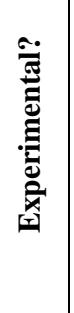 & 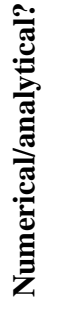 & Equipment type & 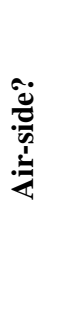 & 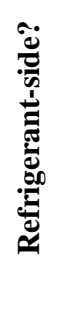 & Refrigerant & $\begin{array}{l}\text { HX type and general } \\
\text { dimensions }\end{array}$ & $\begin{array}{c}\text { Nominal } \\
\text { HX } \\
\text { capacity }\end{array}$ & $\begin{array}{l}\text { Nominal } \\
\text { refrigerant } \\
\text { pressure } \\
\text { range }\end{array}$ & $\begin{array}{l}\text { Nominal } \\
\text { refrigerant } \\
\text { flow rate } \\
\text { range }\end{array}$ & $\begin{array}{l}\text { Maldistribution } \\
\text { effect on HX } \\
\text { capacity }\end{array}$ & Notes \\
\hline $\begin{array}{l}\text { Kærn et al., } \\
2011 \text { [11] }\end{array}$ & & $x$ & Room air-conditioner & $x$ & $\times$ & $\mathrm{R}-410 \mathrm{a}$ & $\begin{array}{l}\text { Fin-tube evaporator, } \\
2 \text { row, } 2 \text { passes, } 18 \\
\text { tubes, ID: } 7.6 \mathrm{~mm} \text {, } \\
\text { OD: } 9.6 \mathrm{~mm} \text {, length: } \\
444.5 \mathrm{~mm}\end{array}$ & $8.8 \mathrm{~kW}$ & $\begin{array}{c}1000- \\
3000 \mathrm{kPa}\end{array}$ & $0.06 \mathrm{~kg} / \mathrm{s}$ & Up to $43.2 \%$ & $\begin{array}{l}\text { RAC system model } \\
\text { shows non-uniform } \\
\text { airflow significantly } \\
\text { reduced capacity } \\
(43 \%) \text {; differing } \\
\text { liq/vap distribution in } \\
\text { distributor had smaller } \\
\text { impact (13\%) and } \\
\text { feeder tube bending } \\
\text { was even less (4\%) }\end{array}$ \\
\hline $\begin{array}{l}\text { Kim et al., } \\
2009 \text { [1] }\end{array}$ & & $x$ & $\begin{array}{l}\text { Residential heat } \\
\text { pump }\end{array}$ & $x$ & $x$ & $\mathrm{R}-410 \mathrm{a}$ & $\begin{array}{l}\text { Fin-tube evaporator, } \\
3 \text { row, } 5 \text { parallel } \\
\text { circuits, } 17 \text { tubes } \\
\text { each }\end{array}$ & $10.5 \mathrm{~kW}$ & $\begin{array}{c}1000- \\
3000 \mathrm{kPa}\end{array}$ & Not stated & Up to $6 \%$ & $\begin{array}{l}\text { Hybrid method for } \\
\text { optimizing refrigerant } \\
\text { distribution in } \\
\text { evaporators was } \\
\text { studied involving small } \\
\text { balancing valves in } \\
\text { reach refrigerant circuit } \\
\text { along with primary } \\
\text { expansion device; } \\
\text { benefits of controlling } \\
\text { the superheat of the } \\
\text { individual tubes using } \\
\text { upstream and } \\
\text { downstream control } \\
\text { valves were } \\
\text { investigated. }\end{array}$ \\
\hline $\begin{array}{l}\text { Lee et al., } \\
2018 \text { [34] }\end{array}$ & $x$ & $x$ & General - fin-tube HX & $x$ & & R-410a & $\begin{array}{l}\text { Fin-tube condenser, } \\
18 \text { tubes per bank in } 3 \\
\text { banks, OD: } 10.5 \mathrm{~mm} \text {, } \\
\text { thickness: } 0.55 \mathrm{~mm} \text {, } \\
\text { length: } 0.46 \mathrm{~m}\end{array}$ & $8.5 \mathrm{~kW}$ & $\begin{array}{c}1000- \\
3000 \mathrm{kPa}\end{array}$ & $23 \mathrm{~g} / \mathrm{s}$ & Up to $11 \%$ & $\begin{array}{l}\text { Integrated CFD- } \\
\text { segmented HX model } \\
\text { used to study effect of } \\
\text { geometric parameters } \\
\text { and air flow rate on air } \\
\text { flow maldistribution; }\end{array}$ \\
\hline
\end{tabular}




\begin{tabular}{|c|c|c|c|c|c|c|c|c|c|c|c|c|}
\hline $\begin{array}{c}\text { Reference } \\
\text { name \& year }\end{array}$ & & 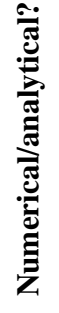 & Equipment type & 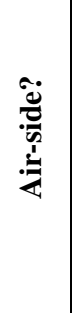 & 萢 & Refrigerant & $\begin{array}{l}\text { HX type and general } \\
\text { dimensions }\end{array}$ & $\begin{array}{l}\text { Nominal } \\
\text { HX } \\
\text { capacity }\end{array}$ & $\begin{array}{l}\text { Nominal } \\
\text { refrigerant } \\
\text { pressure } \\
\text { range }\end{array}$ & $\begin{array}{l}\text { Nominal } \\
\text { refrigerant } \\
\text { flow rate } \\
\text { range }\end{array}$ & $\begin{array}{l}\text { Maldistribution } \\
\text { effect on HX } \\
\text { capacity }\end{array}$ & Notes \\
\hline & & & & & & & & & & & & $\begin{array}{l}\text { CFD model validated } \\
\text { with PIV } \\
\text { measurements; } \\
\text { parameters varied in } \\
\text { study include HX } \\
\text { angle, HX depth, HX } \\
\text { height, air flow rate } \\
\text { and fin type. }\end{array}$ \\
\hline $\begin{array}{l}\text { Li and } \\
\text { Hrnjak, } \\
2015 \text { [7] }\end{array}$ & & $\times$ & $\begin{array}{l}\text { General - } \\
\text { microchannel HX }\end{array}$ & & $x$ & Not stated & $\begin{array}{l}\text { Microchannel } \\
\text { evaporator }\end{array}$ & $\begin{array}{c}2.25- \\
3.6 \mathrm{~kW}\end{array}$ & Not stated & Not stated & Not stated & $\begin{array}{l}\text { Non-contacting, non- } \\
\text { intrusive, Infrared } \\
\text { Thermography } \\
\text { approach to quantify } \\
\text { liquid refrigerant } \\
\text { distribution; validated } \\
\text { against experimental } \\
\text { data. }\end{array}$ \\
\hline $\begin{array}{l}\text { Linde (MSc } \\
\text { thesis), } 2005 \\
{[10]}\end{array}$ & $x$ & & $\begin{array}{l}\text { General - } \\
\text { microchannel HX }\end{array}$ & & $x$ & R-134a & $\begin{array}{l}\text { Microchannel } \\
\text { evaporator, } 30 \\
\text { channels, width: } 18 \\
\text { mm, length: } 1 \mathrm{~m}, 5 \\
\text { ports }(2.86 \times 1.32 \\
\mathrm{mm})\end{array}$ & $\begin{array}{l}5-10 \\
\mathrm{~kW}\end{array}$ & $\begin{array}{c}300-700 \\
\mathrm{kPa}\end{array}$ & $80 \mathrm{~g} / \mathrm{s}$ & Not stated & $\begin{array}{l}\text { Experimental setup to } \\
\text { visualize flow through } \\
\text { a multiport header and } \\
\text { two-phase refrigerant } \\
\text { distribution in } \\
\text { microchannel heat } \\
\text { exchanger; ability to } \\
\text { vary inlet header } \\
\text { geometry and study } \\
\text { influence of tube } \\
\text { number, tube pitch, } \\
\text { refrigerant, heat load, } \\
\text { inlet location and mass } \\
\text { flow rate on } \\
\text { maldistribution. }\end{array}$ \\
\hline
\end{tabular}




\begin{tabular}{|c|c|c|c|c|c|c|c|c|c|c|c|c|}
\hline $\begin{array}{c}\text { Reference } \\
\text { name \& year }\end{array}$ & 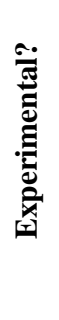 & 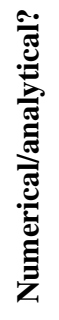 & Equipment type & 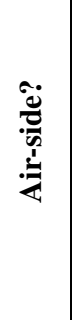 & 萢 & Refrigerant & $\begin{array}{l}\text { HX type and general } \\
\text { dimensions }\end{array}$ & $\begin{array}{l}\text { Nominal } \\
\text { HX } \\
\text { capacity }\end{array}$ & $\begin{array}{l}\text { Nominal } \\
\text { refrigerant } \\
\text { pressure } \\
\text { range }\end{array}$ & $\begin{array}{l}\text { Nominal } \\
\text { refrigerant } \\
\text { flow rate } \\
\text { range }\end{array}$ & $\begin{array}{l}\text { Maldistribution } \\
\text { effect on HX } \\
\text { capacity }\end{array}$ & Notes \\
\hline $\begin{array}{l}\text { Mao et al., } \\
2013 \text { [18] }\end{array}$ & $x$ & $\times$ & $\begin{array}{l}\text { General - } \\
\text { minichannel HX }\end{array}$ & $x$ & $x$ & $\begin{array}{l}\text { R-22 \& R- } \\
134 a\end{array}$ & $\begin{array}{l}\text { Minichannel } \\
\text { condenser, } 2-6 \text { tube } \\
\text { passes, tube height: } \\
21 \mathrm{~mm} \text {, tube width: } \\
16 \mathrm{~mm}, 10 \text { ports }(1 \mathrm{x} \\
1.25 \mathrm{~mm})\end{array}$ & $\begin{array}{c}7.7-9.5 \\
\mathrm{~kW}\end{array}$ & $\begin{array}{c}900- \\
2800 \mathrm{kPa}\end{array}$ & $\begin{array}{c}0.038- \\
0.051 \mathrm{~kg} / \mathrm{s}\end{array}$ & Up to $6 \%$ & $\begin{array}{l}\text { The effects of various } \\
\text { 2D air flow } \\
\text { maldistribution profiles } \\
\text { on HX effectiveness, } \\
\text { capacity and pressure } \\
\text { drop were investigated; } \\
\text { the maximum capacity } \\
\text { reduction and pressure } \\
\text { drop increment were } \\
6 \% \text { and } 34 \% \text {, } \\
\text { respectively. }\end{array}$ \\
\hline $\begin{array}{l}\text { Mohammadi } \\
\text { and } \\
\text { Malayeri, } \\
2013 \text { [35] }\end{array}$ & & $\times$ & $\begin{array}{l}\text { General - shell and } \\
\text { tube HX }\end{array}$ & & $x$ & Crude oil & $\begin{array}{l}\text { Single-phase shell- } \\
\text { tube HX, shell ID: } \\
838.2 \mathrm{~mm} \text {, tube ID: } \\
20.10 \mathrm{~mm} \text {, tube OD: } \\
25.4 \mathrm{~mm} \text {, tube length: } \\
2000 \mathrm{~mm}\end{array}$ & $\begin{array}{l}\text { Not } \\
\text { stated }\end{array}$ & Not stated & $\begin{array}{c}\text { Mean } \\
\text { velocity: } \\
1.2-3.8 \\
\mathrm{~m} / \mathrm{s}\end{array}$ & $\begin{array}{c}\text { Not stated but } \\
\text { maximum flow } \\
\text { velocity } \\
\text { deviation of } \\
25 \%\end{array}$ & $\begin{array}{l}\text { For turbulent, single- } \\
\text { phase flow through the } \\
\text { shell-tube HX, flow } \\
\text { maldistribution was } \\
\text { found to be a function } \\
\text { of tube number; } \\
\text { increased tube number } \\
\text { increased distribution } \\
\text { uniformity. }\end{array}$ \\
\hline $\begin{array}{l}\text { Mohan et } \\
\text { al., } 2014 \\
{[25]}\end{array}$ & $x$ & $x$ & $\begin{array}{l}\text { General - crossflow } \\
\text { automotive HX }\end{array}$ & & $x$ & Water & $\begin{array}{l}\text { Single-phase cross- } \\
\text { flow automobile HX, } \\
\text { channel ID: } 8.57 \mathrm{~mm}\end{array}$ & $\begin{array}{l}\text { Not } \\
\text { stated }\end{array}$ & $101 \mathrm{kPa}$ & $0.035 \mathrm{~kg} / \mathrm{s}$ & Not stated & $\begin{array}{l}\text { Parametric study of } \\
\text { effect of channel } \\
\text { diameter on HX flow } \\
\text { distribution and } \\
\text { pressure drop; } \\
\text { changing individual } \\
\text { channel diameters is } \\
\text { more effective for flow } \\
\text { control distribution } \\
\text { compared to changing } \\
\text { all channel diameters. }\end{array}$ \\
\hline
\end{tabular}




\begin{tabular}{|c|c|c|c|c|c|c|c|c|c|c|c|c|}
\hline $\begin{array}{c}\text { Reference } \\
\text { name \& year }\end{array}$ & 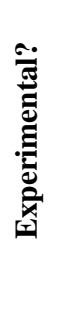 & 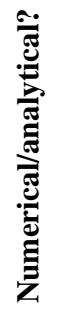 & Equipment type & 苞 & 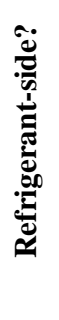 & Refrigerant & $\begin{array}{l}\text { HX type and general } \\
\text { dimensions }\end{array}$ & $\begin{array}{l}\text { Nominal } \\
\text { HX } \\
\text { capacity }\end{array}$ & $\begin{array}{l}\text { Nominal } \\
\text { refrigerant } \\
\text { pressure } \\
\text { range }\end{array}$ & $\begin{array}{l}\text { Nominal } \\
\text { refrigerant } \\
\text { flow rate } \\
\text { range }\end{array}$ & $\begin{array}{l}\text { Maldistribution } \\
\text { effect on HX } \\
\text { capacity }\end{array}$ & Notes \\
\hline $\begin{array}{l}\text { Ozawa et } \\
\text { al., } 1989 \\
{[36]}\end{array}$ & $x$ & $\times$ & $\begin{array}{l}\text { General - two parallel } \\
\text { channels with air- } \\
\text { water flow simulating } \\
\text { flow boiling }\end{array}$ & & $\times$ & $\begin{array}{l}\text { Air-water } \\
\text { mixture }\end{array}$ & $\begin{array}{l}\text { Parallel tube channel } \\
\text { HX, two tubes, ID: } \\
3.1 \mathrm{~mm} \text {, length: } 3.1 \\
\text { m }\end{array}$ & $\begin{array}{l}\text { Not } \\
\text { stated }\end{array}$ & $101 \mathrm{kPa}$ & $\begin{array}{l}\text { Total } \\
\text { volumetric } \\
\text { flux: } \\
0.374 \mathrm{~m} / \mathrm{s}\end{array}$ & Not stated & $\begin{array}{l}\text { Effect of pressure drop } \\
\text { oscillations in two- } \\
\text { phase flow through } \\
\text { parallel channels was } \\
\text { studied; analysis in } \\
\text { paper can be used to } \\
\text { estimate characteristics } \\
\text { of non-uniform flow } \\
\text { distribution and } \\
\text { oscillation }\end{array}$ \\
\hline $\begin{array}{l}\text { Payne and } \\
\text { Domanski } \\
\text { (NIST } \\
\text { report), } \\
2002[15]\end{array}$ & $x$ & $\times$ & General - fin-tube HX & $x$ & $x$ & R-22 & $\begin{array}{l}\text { Fin-tube evaporators, } \\
\text { ID: } 9.53 \mathrm{~mm} \text {, round } \\
\text { tubes }\end{array}$ & $3-8 \mathrm{~kW}$ & $600 \mathrm{kPa}$ & $100 \mathrm{~kg} / \mathrm{h}$ & Up to $43 \%$ & $\begin{array}{l}\text { Effect of smart } \\
\text { refrigerant distributors } \\
\text { and non-uniform air } \\
\text { flow on HX capacity } \\
\text { was studied; capacity } \\
\text { degradation due to } \\
\text { maldistribution could } \\
\text { effectively be restored } \\
\text { by controlling } \\
\text { refrigerant superheat at } \\
\text { evaporator outlets. }\end{array}$ \\
\hline $\begin{array}{l}\text { Razlan et } \\
\text { al., } 2018 \\
{[16]}\end{array}$ & $x$ & & Heat pump system & & $x$ & $\begin{array}{l}\mathrm{R}-134 \mathrm{a}, \\
\text { air-water } \\
\text { mixture }\end{array}$ & $\begin{array}{l}\text { Minichannel } \\
\text { evaporator, multi- } \\
\text { pass, upward flow } \\
\text { minichannels, } 1.7 \text { x } \\
20 \text { mm with } 17 \text { ports, } \\
\text { each port } 0.5 \text { x } 0.8 \\
\text { mm }\end{array}$ & $\begin{array}{l}\text { Not } \\
\text { stated }\end{array}$ & $\begin{array}{c}200- \\
1000 \mathrm{kPa}\end{array}$ & $\begin{array}{c}4.15-8.5 \\
\mathrm{~kg} / \mathrm{h}\end{array}$ & Not stated & $\begin{array}{l}\text { Comparison of flow } \\
\text { patterns of two-phase } \\
\text { refrigerant to air-water } \\
\text { mixture; under the } \\
\text { right conditions, air- } \\
\text { water can be used to } \\
\text { accurately represent } \\
\text { two phase flow; equal } \\
\text { Baker map parameters } \\
\text { resulted in the greatest }\end{array}$ \\
\hline
\end{tabular}




\begin{tabular}{|c|c|c|c|c|c|c|c|c|c|c|c|c|}
\hline $\begin{array}{c}\text { Reference } \\
\text { name \& year }\end{array}$ & 递 & 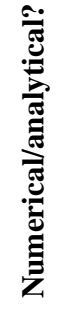 & Equipment type & 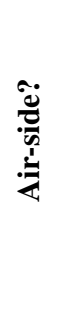 & 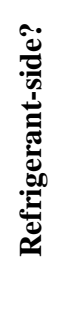 & Refrigerant & $\begin{array}{l}\text { HX type and general } \\
\text { dimensions }\end{array}$ & $\begin{array}{l}\text { Nominal } \\
\text { HX } \\
\text { capacity }\end{array}$ & $\begin{array}{l}\text { Nominal } \\
\text { refrigerant } \\
\text { pressure } \\
\text { range }\end{array}$ & $\begin{array}{l}\text { Nominal } \\
\text { refrigerant } \\
\text { flow rate } \\
\text { range }\end{array}$ & $\begin{array}{l}\text { Maldistribution } \\
\text { effect on HX } \\
\text { capacity }\end{array}$ & Notes \\
\hline & & & & & & & & & & & & $\begin{array}{l}\text { similarity in flow } \\
\text { pattern. }\end{array}$ \\
\hline $\begin{array}{l}\text { Rossetti et } \\
\text { al., } 2015 \\
{[37]}\end{array}$ & & $x$ & Open display cabinet & $x$ & & Not stated & $\begin{array}{l}\text { Fin-tube evaporator, } \\
10 \text { rows, } 2 \text { tube }\end{array}$ & $\begin{array}{c}\text { Not } \\
\text { stated }\end{array}$ & Not stated & Not stated & Up to $10 \%$ & $\begin{array}{l}\text { Thermofluid model } \\
\text { utilized thermal } \\
\text { equivalence model for } \\
\text { the evaporator fins, } \\
\text { reducing } \\
\text { computational cost and } \\
1.2 \text { million nodes, a } \\
\text { factor of } 10 \text { lower } \\
\text { compared to similar } \\
\text { models in the } \\
\text { literature. }\end{array}$ \\
\hline $\begin{array}{l}\text { Said et al., } \\
2014 \text { [26] }\end{array}$ & & $x$ & $\begin{array}{l}\text { General - header and } \\
\text { tube HX }\end{array}$ & & $x$ & $\begin{array}{l}\text { Industrial } \\
\text { oil }\end{array}$ & $\begin{array}{l}\text { Single-phase fin-tube } \\
\text { HX, } 9 \text { tubes, ID: } 25 \\
\text { mm, length: } 400 \mathrm{~mm}\end{array}$ & $\begin{array}{l}\text { Not } \\
\text { stated }\end{array}$ & $600 \mathrm{~Pa}$ & $0.25 \mathrm{~kg} / \mathrm{s}$ & $\begin{array}{l}\text { Not stated but } \\
\text { up to } 12 x \text { flow } \\
\text { rate deviation }\end{array}$ & $\begin{array}{l}\text { Study on normalizing } \\
\text { inlet vena-contracta to } \\
\text { evenly distribute flow } \\
\text { through HX header; } \\
\text { two approaches } \\
\text { involving reduced and } \\
\text { increased inlet } \\
\text { diameters resulted in } \\
\text { balance between flow } \\
\text { maldistribution } \\
\text { mitigation and pressure } \\
\text { drop. }\end{array}$ \\
\hline $\begin{array}{l}\text { Shojaeefard } \\
\text { et al., } 2017 \\
\text { [38] }\end{array}$ & $x$ & $x$ & $\begin{array}{l}\text { General - } \\
\text { minichannel HX }\end{array}$ & & $x$ & $\mathrm{R}-134 \mathrm{a}$ & $\begin{array}{l}\text { Minichannel } \\
\text { condenser, } 4 \text { passes, } \\
31 \text { tubes, } 7 \text { ports, tube } \\
\text { width: } 10 \mathrm{~mm} \text {, tube } \\
\text { length: } 546 \mathrm{~mm}\end{array}$ & $\begin{array}{c}2.34- \\
13.69 \\
\mathrm{~kW}\end{array}$ & $\begin{array}{c}100- \\
3500 \mathrm{kPa}\end{array}$ & $\begin{array}{c}0-600 \\
\mathrm{~kg} / \mathrm{h}\end{array}$ & Up to $4 \%$ & $\begin{array}{l}\text { Hybrid simulation } \\
\text { method involving } \\
\text { simultaneous CFD } \\
\text { model for flow through } \\
\text { header and FE model } \\
\text { for flow through }\end{array}$ \\
\hline
\end{tabular}




\begin{tabular}{|c|c|c|c|c|c|c|c|c|c|c|c|c|}
\hline $\begin{array}{c}\text { Reference } \\
\text { name \& year }\end{array}$ & 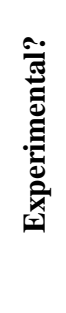 & 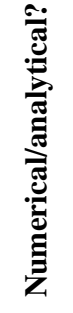 & Equipment type & 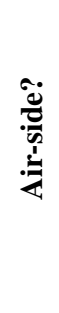 & 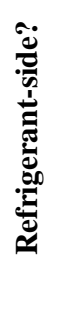 & Refrigerant & $\begin{array}{l}\text { HX type and general } \\
\text { dimensions }\end{array}$ & $\begin{array}{l}\text { Nominal } \\
\text { HX } \\
\text { capacity }\end{array}$ & $\begin{array}{l}\text { Nominal } \\
\text { refrigerant } \\
\text { pressure } \\
\text { range }\end{array}$ & $\begin{array}{l}\text { Nominal } \\
\text { refrigerant } \\
\text { flow rate } \\
\text { range }\end{array}$ & $\begin{array}{l}\text { Maldistribution } \\
\text { effect on } \mathbf{H X} \\
\text { capacity }\end{array}$ & Notes \\
\hline & & & & & & & & & & & & $\begin{array}{l}\text { channels; effects of } \\
\text { tube protrusion depth, } \\
\text { inlet tube location, } \\
\text { inlet tube diameter and } \\
\text { combinations on flow } \\
\text { maldistribution were } \\
\text { studied. }\end{array}$ \\
\hline $\begin{array}{l}\text { Tuo and } \\
\text { Hrnjak, } \\
2013 \text { [39] }\end{array}$ & $x$ & $x$ & $\begin{array}{l}\text { Automotive air- } \\
\text { conditioner }\end{array}$ & & $x$ & R-134a & $\begin{array}{l}\text { Microchannel } \\
\text { evaporator, } 1 \text { pass, } 34 \\
\text { tubes, } 19 \text { ports, } \\
\text { hydraulic diameter: } \\
0.8 \mathrm{~mm}\end{array}$ & $\begin{array}{l}\text { Not } \\
\text { stated }\end{array}$ & $\begin{array}{c}299-387 \\
\mathrm{kPa}\end{array}$ & $10-30 \mathrm{~g} / \mathrm{s}$ & Up to $25 \%$ & $\begin{array}{l}\text { Study on effect of } \\
\text { header pressure drop } \\
\text { on flow } \\
\text { maldistribution; } \\
\text { header-induced flow } \\
\text { maldistribution still } \\
\text { exists when quality } \\
\text { induced } \\
\text { maldistribution is } \\
\text { eliminated; limiting } \\
\text { outlet header pressure } \\
\text { drop by adjusting } \\
\text { outlet header diameter } \\
\text { significantly limited } \\
\text { HX capacity } \\
\text { degradation. }\end{array}$ \\
\hline $\begin{array}{l}\text { Vist and } \\
\text { Pettersen, } \\
2004 \text { [40] }\end{array}$ & $x$ & & $\begin{array}{l}\text { Automotive air- } \\
\text { conditioner }\end{array}$ & & $x$ & $\mathrm{R}-134 \mathrm{a}$ & $\begin{array}{l}\text { Minichannel } \\
\text { evaporator, } 10 \\
\text { parallel circular } \\
\text { tubes, ID: } 4 \mathrm{~mm} \text {, } \\
\text { length: } 0.9 \mathrm{~m}\end{array}$ & $5 \mathrm{~kW}$ & $\begin{array}{c}690-710 \\
\mathrm{kPa}\end{array}$ & $\begin{array}{c}0.025- \\
0.042 \mathrm{~kg} / \mathrm{s}\end{array}$ & Not stated & $\begin{array}{l}\text { Effects of inlet vapor } \\
\text { quality, heat load on } \\
\text { individual tubes, } \\
\text { manifold diameter, } \\
\text { manifold inlet tube } \\
\text { length and HX } \\
\text { orientation on flow } \\
\text { maldistribution were } \\
\text { studied. }\end{array}$ \\
\hline
\end{tabular}




\begin{tabular}{|c|c|c|c|c|c|c|c|c|c|c|c|c|}
\hline $\begin{array}{c}\text { Reference } \\
\text { name \& year }\end{array}$ & 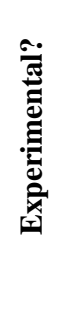 & 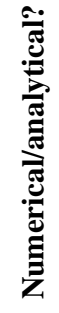 & Equipment type & 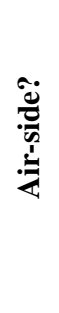 & 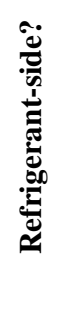 & Refrigerant & $\begin{array}{l}\text { HX type and general } \\
\text { dimensions }\end{array}$ & $\begin{array}{l}\text { Nominal } \\
\text { HX } \\
\text { capacity }\end{array}$ & $\begin{array}{l}\text { Nominal } \\
\text { refrigerant } \\
\text { pressure } \\
\text { range }\end{array}$ & $\begin{array}{l}\text { Nominal } \\
\text { refrigerant } \\
\text { flow rate } \\
\text { range }\end{array}$ & $\begin{array}{l}\text { Maldistribution } \\
\text { effect on HX } \\
\text { capacity }\end{array}$ & Notes \\
\hline $\begin{array}{l}\text { Wen et al., } \\
2006 \text { [41] }\end{array}$ & $x$ & & $\begin{array}{l}\text { General - Plate-fin } \\
\text { HX }\end{array}$ & $x$ & & Air & $\begin{array}{l}\text { Single-phase plate-fin } \\
\text { HX, inlet baffles } 600 \\
\text { x } 260 \mathrm{~mm} \text {, hole ID: } \\
10-30 \mathrm{~mm}\end{array}$ & $\begin{array}{l}\text { Not } \\
\text { stated }\end{array}$ & $\begin{array}{l}400 \mathrm{~Pa} \\
\text { drop } \\
\text { across } \\
\text { baffle }\end{array}$ & $\begin{array}{c}\text { Mean } \\
\text { velocity: } 4 \\
\mathrm{~m} / \mathrm{s}\end{array}$ & $\begin{array}{l}\text { Not stated but } \\
\text { maximum flow } \\
\text { velocity ratio } \\
\text { of } 23.2\end{array}$ & $\begin{array}{l}\text { PIV was used to study } \\
\text { the flow distribution } \\
\text { resulting from inlet } \\
\text { baffles of varying } \\
\text { geometry; by } \\
\text { optimizing the } \\
\text { geometry, the ratio of } \\
\text { max to min velocity } \\
\text { through header holes } \\
\text { was reduced from } 23.2 \\
\text { to } 1.76 \text {. }\end{array}$ \\
\hline $\begin{array}{l}\text { Yaïci et al., } \\
2016 \text { [42] }\end{array}$ & & $\times$ & $\begin{array}{l}\text { General - plate-fin } \\
\text { HX }\end{array}$ & $\times$ & & Air/water & $\begin{array}{l}\text { Single-phase plate-fin } \\
\text { HX, } 4 \text { row, } 4 \text { tubes, } \\
\text { OD: } 9.97 \mathrm{~mm}\end{array}$ & $\begin{array}{l}\text { Not } \\
\text { stated }\end{array}$ & Not stated & $\begin{array}{c}\text { Mean } \\
\text { velocity: } 4 \\
\mathrm{~m} / \mathrm{s}\end{array}$ & Not stated & $\begin{array}{l}\text { 3D CFD used to study } \\
\text { the effect of inlet air } \\
\text { flow maldistribution on } \\
\text { design and thermal- } \\
\text { hydraulic performance } \\
\text { of HX; parameters } \\
\text { included Reynolds } \\
\text { number, } \\
\text { longitudinal/transversal } \\
\text { tube pitch and fin } \\
\text { pitch; Up to } 67 \% \\
\text { deviation in friction } \\
\text { factor and Colburn } \\
\text { factor was determined } \\
\text { for non-uniform vs. } \\
\text { uniform flow with } \\
\text { varying fin pitch, for } \\
\text { example. }\end{array}$ \\
\hline $\begin{array}{l}\text { Yang, Wen } \\
\text { et al., } 2017 \\
\text { [43] }\end{array}$ & & $x$ & $\begin{array}{l}\text { General - plate-fin } \\
\text { HX }\end{array}$ & $x$ & & Air & $\begin{array}{l}\text { Single-phase plate-fin } \\
\text { HX, punched baffle, } \\
\text { hole ID: } 10-15 \mathrm{~mm}\end{array}$ & $\begin{array}{l}\text { Not } \\
\text { stated }\end{array}$ & $\begin{array}{c}0.5-12 \\
\text { kPa drop } \\
\text { across HX }\end{array}$ & $0.002 \mathrm{~kg} / \mathrm{s}$ & Up to $46.8 \%$ & $\begin{array}{l}\text { CFD used to obtain } \\
\text { flow distribution in } \\
\text { core of plate-fin HX; }\end{array}$ \\
\hline
\end{tabular}




\begin{tabular}{|c|c|c|c|c|c|c|c|c|c|c|c|c|}
\hline $\begin{array}{c}\text { Reference } \\
\text { name \& year }\end{array}$ & 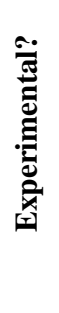 & 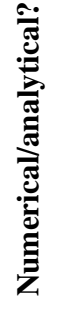 & Equipment type & 苞 & 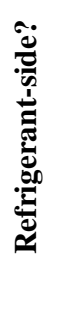 & Refrigerant & $\begin{array}{l}\text { HX type and general } \\
\text { dimensions }\end{array}$ & $\begin{array}{l}\text { Nominal } \\
\text { HX } \\
\text { capacity }\end{array}$ & $\begin{array}{c}\text { Nominal } \\
\text { refrigerant } \\
\text { pressure } \\
\text { range }\end{array}$ & $\begin{array}{l}\text { Nominal } \\
\text { refrigerant } \\
\text { flow rate } \\
\text { range }\end{array}$ & $\begin{array}{l}\text { Maldistribution } \\
\text { effect on HX } \\
\text { capacity }\end{array}$ & Notes \\
\hline & & & & & & & & & & & & $\begin{array}{l}\text { by adjusting geometry, } \\
\text { HX effectiveness, } \\
\text { maldistribution } \\
\text { parameter and pressure } \\
\text { drop are significantly } \\
\text { affected for non- } \\
\text { uniform flow vs. } \\
\text { uniform flow. }\end{array}$ \\
\hline $\begin{array}{l}\text { Yang, } \\
\text { Talmor et } \\
\text { al., } 2017 \\
{[28]}\end{array}$ & $x$ & $\times$ & $\begin{array}{l}\text { General - flow } \\
\text { control using } \\
\text { electrohydrodynamics }\end{array}$ & & $x$ & $\begin{array}{l}\text { Novec } \\
7600\end{array}$ & $\begin{array}{l}\text { Single-phase parallel } \\
\text { minichannels, } 3 \\
\text { tubes, ID: } 1 \mathrm{~mm} \text {, } \\
\text { length: } 635 \mathrm{~mm}\end{array}$ & $\begin{array}{l}\text { Not } \\
\text { stated }\end{array}$ & $101 \mathrm{kPa}$ & $\begin{array}{l}4-7 \\
\mathrm{~mL} / \mathrm{min}\end{array}$ & Not stated & $\begin{array}{l}\text { Electrohydrodynamics } \\
\text { used to redistribute } \\
\text { artificially induced } \\
\text { maldistribution in } 3 \\
\text { parallel tubes; flow } \\
\text { rates directed to } \\
\text { specific tubes with } \\
\text { precise control; } \\
\text { suitable for small- } \\
\text { scale, highly branched } \\
\text { thermal control } \\
\text { systems. }\end{array}$ \\
\hline $\begin{array}{l}\text { Yashar et } \\
\text { al., } 2015 \\
{[27]}\end{array}$ & $x$ & $\times$ & $\begin{array}{l}\text { Rooftop air- } \\
\text { conditioner }\end{array}$ & $x$ & & R-410a & $\begin{array}{l}\text { Fin-tube evaporator, } \\
144 \text { tubes, } 4 \text { rows, } 16 \\
\text { circuits, OD: } 9.52 \\
\text { mm }\end{array}$ & $26.4 \mathrm{~kW}$ & $\begin{array}{c}500- \\
3500 \mathrm{kPa}\end{array}$ & Not stated & Up to $2.2 \%$ & $\begin{array}{l}\text { Effect of refrigerant } \\
\text { circuit optimization } \\
\text { was studied; results } \\
\text { show that success of } \\
\text { the proposed } \\
\text { optimization concept } \\
\text { depends strongly on } \\
\text { the availability of } \\
\text { simple but accurate } \\
\text { measurement of air- } \\
\text { side velocity profile }\end{array}$ \\
\hline
\end{tabular}




\begin{tabular}{|c|c|c|c|c|c|c|c|c|c|c|c|c|}
\hline $\begin{array}{c}\text { Reference } \\
\text { name \& year }\end{array}$ & 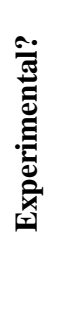 & 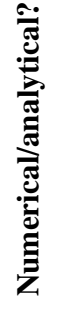 & Equipment type & 芦 & 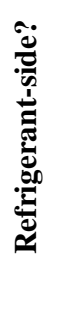 & Refrigerant & $\begin{array}{l}\text { HX type and general } \\
\text { dimensions }\end{array}$ & $\begin{array}{l}\text { Nominal } \\
\text { HX } \\
\text { capacity }\end{array}$ & $\begin{array}{c}\text { Nominal } \\
\text { refrigerant } \\
\text { pressure } \\
\text { range }\end{array}$ & $\begin{array}{l}\text { Nominal } \\
\text { refrigerant } \\
\text { flow rate } \\
\text { range }\end{array}$ & $\begin{array}{l}\text { Maldistribution } \\
\text { effect on HX } \\
\text { capacity }\end{array}$ & Notes \\
\hline & & & & & & & & & & & & $\begin{array}{l}\text { and improved CFD } \\
\text { models. }\end{array}$ \\
\hline $\begin{array}{l}\text { Zhang et al., } \\
2015 \text { [4] }\end{array}$ & $x$ & & $\begin{array}{l}\text { General - plate-fin } \\
\text { HX }\end{array}$ & & $x$ & Air & $\begin{array}{l}\text { Single-phase plate-fin } \\
\mathrm{HX}, 30 \text { channels, } 6.5 \\
\text { x } 2 \mathrm{~mm} \text { channels }\end{array}$ & $\begin{array}{l}\text { Not } \\
\text { stated }\end{array}$ & Not stated & $\begin{array}{c}\text { Mean } \\
\text { velocity: } 4 \\
\mathrm{~m} / \mathrm{s}\end{array}$ & Not stated & $\begin{array}{l}\text { Effect on distributor } \\
\text { inlet angle and } \\
\text { configuration on flow } \\
\text { distribution was } \\
\text { studied; thermal } \\
\text { performance change } \\
\text { due to flow } \\
\text { maldistribution due to } \\
\text { different distributors } \\
\text { was investigated; the } \\
\text { degree of temperature } \\
\text { non-uniformity was } \\
\text { reduced from } 1.078 \text { to } \\
0.712 \text { using the } \\
\text { improved distributor. }\end{array}$ \\
\hline $\begin{array}{l}\text { Zou et al. } \\
\text { (ASHRAE } \\
\text { NY-14- } \\
\text { C010), } 2014 \\
{[21]}\end{array}$ & $x$ & $\times$ & $\begin{array}{l}\text { General - } \\
\text { microchannel HX }\end{array}$ & & $x$ & $\mathrm{R}-134 \mathrm{a}$ & $\begin{array}{l}\text { Microchannel } \\
\text { evaporator, hydraulic } \\
\text { diameter: } 0.5 \mathrm{~mm} \text {, } \\
\text { header ID: } 15.44 \mathrm{~mm}\end{array}$ & $\begin{array}{c}0.2- \\
0.65 \mathrm{~kW}\end{array}$ & Not stated & $4.19 \mathrm{~g} / \mathrm{s}$ & Up to $48 \%$ & $\begin{array}{l}\text { Oil added to refrigerant } \\
\text { to study effect on two- } \\
\text { phase refrigerant flow } \\
\text { in vertical header; } \\
\text { small oil circulation } \\
\text { rate (OCR) made } \\
\text { distribution worse, but } \\
\text { this effect reduced with } \\
\text { higher OCR; } \\
\text { visualization showed } \\
\text { greater amount of oil } \\
\text { enhanced mixing } \\
\text { between phases, } \\
\text { improved distribution }\end{array}$ \\
\hline
\end{tabular}




\begin{tabular}{|c|c|c|c|c|c|c|c|c|c|c|c|c|}
\hline $\begin{array}{c}\text { Reference } \\
\text { name \& year }\end{array}$ & 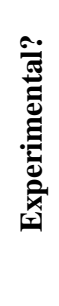 & 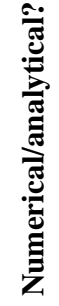 & Equipment type & 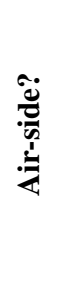 & 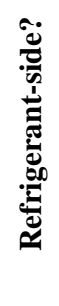 & Refrigerant & $\begin{array}{l}\text { HX type and general } \\
\text { dimensions }\end{array}$ & $\begin{array}{c}\text { Nominal } \\
\text { HX } \\
\text { capacity }\end{array}$ & $\begin{array}{c}\text { Nominal } \\
\text { refrigerant } \\
\text { pressure } \\
\text { range }\end{array}$ & $\begin{array}{l}\text { Nominal } \\
\text { refrigerant } \\
\text { flow rate } \\
\text { range }\end{array}$ & $\begin{array}{l}\text { Maldistribution } \\
\text { effect on HX } \\
\text { capacity }\end{array}$ & Notes \\
\hline & & & & & & & & & & & & $\begin{array}{l}\text { and reduced capacity } \\
\text { degradation. }\end{array}$ \\
\hline $\begin{array}{l}\text { Zou and } \\
\text { Hrnjak } \\
\text { (ACRC } \\
\text { report), } \\
2014 \text { [23] }\end{array}$ & $\times$ & $\times$ & $\begin{array}{l}\text { General - reversible } \\
\text { microchannel HX }\end{array}$ & & $x$ & $\begin{array}{l}\text { R-134a, R- } \\
\text { 410a, R- } \\
\text { 32, R245fa }\end{array}$ & $\begin{array}{l}\text { Microchannel HX, } \\
\text { outdoor reversible, } \\
\text { vertical header, } \\
\text { hydraulic diameter: } \\
0.5 \mathrm{~mm} \text {, header ID: } \\
15.44 \mathrm{~mm}\end{array}$ & Various & $\begin{array}{c}500- \\
4000 \mathrm{kPa}\end{array}$ & $\begin{array}{l}2.14 \text { to } \\
6.25 \mathrm{~g} / \mathrm{s}\end{array}$ & Up to $30 \%$ & $\begin{array}{l}\text { Along with detailed } \\
\text { experimental } \\
\text { measurements and } \\
\text { modeling, flow } \\
\text { visualization in } \\
\text { transparent headers } \\
\text { was performed; effects } \\
\text { of inlet conditions, } \\
\text { header geometry, fluid } \\
\text { properties and } \\
\text { refrigerant distribution } \\
\text { among microchannel } \\
\text { tubes were } \\
\text { investigated; } \\
\text { refrigerant distribution } \\
\text { was found to be related } \\
\text { to size of churn flow in } \\
\text { header (also affected } \\
\text { by fluid properties); } \\
\text { influence of oil } \\
\text { mixture was also } \\
\text { studied; based on } \\
\text { experimental results, a } \\
\text { distribution function } \\
\text { was derived to model } \\
\text { refrigerant distribution } \\
\text { and predict HX } \\
\text { capacity degradation. }\end{array}$ \\
\hline $\begin{array}{l}\text { Zou et al. } \\
\text { (ASHRAE }\end{array}$ & $\times$ & $x$ & $\begin{array}{l}\text { General - } \\
\text { microchannel HX }\end{array}$ & & $\times$ & $\mathrm{R}-410 \mathrm{a}$ & $\begin{array}{l}\text { Microchannel } \\
\text { evaporator, hydraulic }\end{array}$ & $\begin{array}{c}0.3-1.3 \\
\mathrm{~kW}\end{array}$ & $1000 \mathrm{kPa}$ & $\begin{array}{l}2.14 \text { to } \\
6.25 \mathrm{~g} / \mathrm{s}\end{array}$ & Up to $40 \%$ & $\begin{array}{l}\text { Maldistribution effects } \\
\text { in multi-pass }\end{array}$ \\
\hline
\end{tabular}




\begin{tabular}{|c|c|c|c|c|c|c|c|c|c|c|c|c|}
\hline $\begin{array}{c}\text { Reference } \\
\text { name \& year }\end{array}$ & 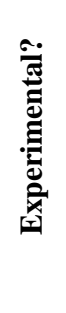 & 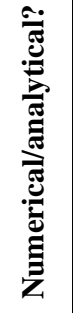 & Equipment type & 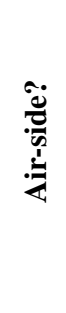 & 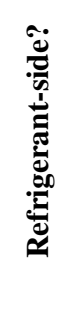 & Refrigerant & $\begin{array}{l}\text { HX type and general } \\
\text { dimensions }\end{array}$ & $\begin{array}{c}\text { Nominal } \\
\text { HX } \\
\text { capacity }\end{array}$ & $\begin{array}{l}\text { Nominal } \\
\text { refrigerant } \\
\text { pressure } \\
\text { range }\end{array}$ & $\begin{array}{l}\text { Nominal } \\
\text { refrigerant } \\
\text { flow rate } \\
\text { range }\end{array}$ & $\begin{array}{l}\text { Maldistribution } \\
\text { effect on HX } \\
\text { capacity }\end{array}$ & Notes \\
\hline $\begin{array}{l}\text { NY-14- } \\
037), 2014 \\
{[22]}\end{array}$ & & & & & & & $\begin{array}{l}\text { diameter: } 0.5 \mathrm{~mm} \text {, } \\
\text { header ID: } 15.44 \mathrm{~mm}\end{array}$ & & & & & $\begin{array}{l}\text { evaporator with } \\
\text { upward flow header; } \\
\text { flow regimes affected } \\
\text { by inlet conditions and } \\
\text { header geometry; } \\
\text { capacity degradation } \\
\text { due to non-uniform } \\
\text { flow in one pass of HX } \\
\text { was quantified. } \\
\text { Comparison between } \\
\text { model and } \\
\text { experimental results } \\
\text { showed maldistribution } \\
\text { was more significant in } \\
\text { two-pass HX. }\end{array}$ \\
\hline $\begin{array}{l}\text { Zou et al., } \\
2014 \text { [44] }\end{array}$ & $x$ & $x$ & $\begin{array}{l}\text { General - } \\
\text { microchannel HX }\end{array}$ & & $x$ & $\begin{array}{l}\text { R-410a \& } \\
\text { R-134a }\end{array}$ & $\begin{array}{l}\text { Microchannel } \\
\text { evaporator, hydraulic } \\
\text { diameter: } 0.5 \mathrm{~mm} \text {, } \\
\text { header ID: } 15.44 \mathrm{~mm}\end{array}$ & $\begin{array}{c}0.3-1.3 \\
\mathrm{~kW}\end{array}$ & $\begin{array}{c}400- \\
1000 \mathrm{kPa}\end{array}$ & $\begin{array}{l}2.14 \text { to } \\
6.25 \mathrm{~g} / \mathrm{s}\end{array}$ & Up to $50 \%$ & $\begin{array}{l}\text { Same as above, } \\
\text { including R-134a } \\
\text { refrigerant and } \\
\text { additional } \\
\text { measurements }\end{array}$ \\
\hline
\end{tabular}

